\title{
Integrated assessment of policy interventions for promoting sustainable irrigation in semi-arid environments: A hydro-economic modeling approach
}

\author{
Irene Blanco-Gutiérrez ，Consuelo Varela-Ortega , David R. Purkey
}

Keywords:

Water management

Sustainable irrigation

Hydro-economic modeling

Policy analysis

Semi-arid regions

\begin{abstract}
A B S T R A C T
Sustaining irrigated agriculture to meet food production needs while maintaining aquatic ecosystems is at the heart of many policy debates in various parts of the world, especially in arid and semi-arid areas. Researchers and practitioners are increasingly calling for integrated approaches, and policy-makers are progressively supporting the inclusion of ecological and social aspects in water management programs. This paper contributes to this policy debate by providing an integrated economic-hydrologic modeling framework that captures the socio-economic and environmental effects of various policy initiatives and climate variability. This modeling integration includes a risk-based economic optimization model and a hydrologic water management simulation model that have been specified for the Middle Guadiana basin, a vulnerable drought-prone agro-ecological area with highly regulated river systems in southwest Spain. Namely, two key water policy interventions were investigated: the implementation of minimum environmental flows (supported by the European Water Framework Directive, EU WFD), and a reduction in the legal amount of water delivered for irrigation (planned measure included in the new Guadiana River Basin Management Plan, GRBMP, still under discussion). Results indicate that current patterns of excessive water use for irrigation in the basin may put environmental flow demands at risk, jeopardizing the WFD's goal of restoring the 'good ecological status' of water bodies by 2015. Conflicts between environmental and agricultural water uses will be stressed during prolonged dry episodes, and particularly in summer low-flow periods, when there is an important increase of crop irrigation water requirements. Securing minimum stream flows would entail a substantial reduction in irrigation water use for rice cultivation, which might affect the profitability and economic viability of small rice-growing farms located upstream in the river. The new GRBMP could contribute to balance competing water demands in the basin and to increase economic water productivity, but might not be sufficient to ensure the provision of environmental flows as required by the WFD. A thoroughly revision of the basin's water use concession system for irrigation seems to be needed in order to bring the GRBMP in line with the WFD objectives. Furthermore, the study illustrates that social, economic, institutional, and technological factors, in addition to bio-physical conditions, are important issues to be considered for designing and developing water management strategies. The research initiative presented in this paper demonstrates that hydro-economic models can explicitly integrate all these issues, constituting a valuable tool that could assist policy makers for implementing sustainable irrigation policies.
\end{abstract}

\section{Introduction}

Water is a vital resource for life, but also a critical limiting factor for economic and social development in many parts of the world.
Water scarcity and drought situations are increasing the pressure on water resources and the environment, as well as leading to growing conflicts among competing water use sectors and regions (Gleick et al., 2009; World Bank, 2006).

In Spain, as in many other arid and semi-arid regions, irrigated agriculture is responsible for most consumptive water use and plays an important role in sustaining rural livelihoods (Lopez-Gunn et al., 2012; Varela-Ortega, 2007). Historically, publicly-funded irrigation 
development plans promoted irrigation expansion and economic growth in agrarian Spain, but increased environmental damage and led to excessive and inefficient exploitation of water resources, raising serious questions over the environmental and economic sustainability of irrigated systems (Varela-Ortega, 2011). In recent years, increased focus has been placed on the protection and better allocation of water resources, and therefore on broader integrated water resources management strategies, policies, and tools.

In the European (EU) policy arena, water policies and agricultural policies are also moving in the direction of integrated resources management. Over the last decade, the two crucial EU policies in relation to irrigated agriculture -the Common Agricultural Policy (CAP) and the Water Framework Directive (WFD) have progressed toward common objectives and strategies in order to protect and improve the natural environment.

The last review of the CAP, the 'Health Check' reform (EC, 2009), seeks to increase the competitiveness and sustainability of EU agriculture by supporting market-oriented and environmentally friendly agricultural production. The reform introduces new income support schemes for farmers, promotes greener farming practices, and includes water and climate change as specific requirements in its programs. On the other hand, the WFD (EC, 2000) places special emphasis on environmental protection objectives aiming to achieve a sustainable 'Good Ecological Status' (GES) of all water bodies across every European river basin district by 2015. As opposed to earlier segmented EU water protection programs, the WFD adopts a multi-sectoral and holistic river basin management approach and offers an important opportunity to incorporate economic instruments and integrated management tools and strategies into water resources planning (Heinz et al., 2007).

Recent shifts in water management paradigms and policies have fostered the development of integrated multi-disciplinary methods for supporting water decision-making. Among the extensive suite of methods used for integrated water management (Bayesian networks, metamodels, risk-assessment approaches, and others, see Croke et al., 2007), hydro-economic models have emerged as privileged tools to assist policy-makers in the assessment and development of sustainable water management strategies (Booker et al., 2012). The combination of economic insights with hydrology and engineering processes offers a more realistic and coherent framework to analyze the potential implications of water management and climate-related issues for all water users (Brouwer and Hofkes, 2008; Medellín-Azuara et al., 2009). Hydro-economic models improve decision-making by providing relevant insights in terms of water valuation and allocation, integrated water planning and institutional design, and have been successfully used in a wide variety of settings as reported in Harou et al. (2009). Recent hydro-economic model applications have been developed to study water quality problems and environmental restoration issues (e.g. Becker and Friedler, 2013; Qureshi et al., 2008; Yang et al., 2007), droughts and climate change impacts (e.g. Harou et al., 2010; Maneta et al., 2009), water allocation strategies (e.g. George et al., 2011; Gohar and Ward, 2010), water pricing and resource costs (e.g. Riegels et al., 2011; Ward and Pulido-Velázquez, 2009), and land use planning policies (e.g. Ahrends et al., 2008). Many of these applications use hydrologic simulation models, such as MIKE BASIN (Jha and Gupta, 2003), RIBASIM (WL Delft Hydraulics, 2004), MODSIM (Labadie, 2011), SWAT (Neitsch et al., 2011), and WaSIM (Schulla, 2012), in combination with profit optimization techniques, following a compartmental hydro-economic approach (i.e, the economic and hydrological aspects are separated in two independent, but interconnected models). As compared with fully integrated (holistic) models, compartmental approaches permit to combine complex economic and hydrologic tools that can be independently solved and therefore, more easily calibrated, and improved. Nonetheless, they face information transfer difficulties that can be partially surpassed by the adoption of data exchange tools (Brouwer and Hofkes, 2008; McKinney et al., 1999).

Along the same lines, this paper present the development and application of a novel economic-hydrologic modeling framework to evaluate the potential impacts of different policy interventions and a change in climate on the hydrological and agrarian systems of the Middle Guadiana basin, a vulnerable drought-prone agro-ecological area with highly fragmented and regulated river systems in southwest Spain. The integrated modeling framework includes a risk-based economic optimization model of farm decision-making and a hydrologic water resources simulation model WEAP ('Water Evaluation and Planning' system) (Sieber and Purkey, 2011). Both models work in standalone mode, but they are connected through an automated simulation engine, which allows the user to sequentially run the models.

To date, few studies have used WEAP in combination with socioeconomic models. Some examples are those of Purkey et al. (2008), where WEAP and econometric methods are applied to assess climate change impacts on water supply and agricultural water management; and of Kemp-Benedict et al. (2010), that illustrate the integration of WEAP with Knowledge Elicitation Tools (KnETs) for sustainability planning. Lately, Varela-Ortega et al. (2011) use a stylized water management WEAP application and a farm-based economic optimization model to analyze water and climate uncertainties on groundwater-supplied irrigation systems. In contrast to the integrated framework developed by Varela-Ortega et al. (2011) that offers a one-way flow of information from the economic to the hydrologic model, the present study includes feedback loops between socio-economic and hydrologic processes and makes use of a hydrologic module in addition to a water management module to better capture all aspects of catchment hydrology. Hence, the present research takes a step forward in terms of model performance, application and linking.

\section{The study region and the policy problem}

The Middle Guadiana basin constitutes an emblematic case study where to apply and learn for integrated modeling in guiding and supporting water management decision-making. The basin is located on the south-western plateau of the Iberian Peninsula in Spain, and its left boundary acts as a natural border between Portugal and Spain (see Fig. 1). The Middle Guadiana extends over an area of $27,319 \mathrm{~km}^{2}$ within Spanish territory and is home to 762,131 people.

The region exhibits a semi-arid Mediterranean-Continental climate, characterized by recurrent drought spells and normal years with hot, dry summers and warm, wet winters. The cultivated land covers nearly $1,200,000$ ha ( $44 \%$ of the total surface of the basin), of which 130,000 ha are irrigated and almost totally dependent of surface water. Although irrigated agriculture accounts for less than $5 \%$ of the land area, it is by far the largest user of water (irrigation represents up to $93 \%$ of all water withdrawn) and one of the most important economic drivers in the region ( $\mathrm{CHG}, 2008$ ).

Similarly to other agricultural areas in Spain, this region has beneficiated from public plans for the development of extensive irrigation systems. Since 1952, year in which the first publicly funded development plan (the 'Plan Badajoz') was launched, the irrigated area has tripled and numerous hydraulic infrastructures (dams, reservoirs, canals) have been built. At present, the basin holds 43 large dams with a total storage capacity of almost $8000 \mathrm{Mm}^{3}$ (nearly, $15 \%$ of the total reservoir capacity in Spain), which makes the Middle Guadiana basin one of the most regulated basins in Europe ( $\mathrm{CHG}$, 2008). Irrigation expansion in the area has helped to partially mitigate the impacts of the region's once endemic drought and has brought about socio-economic prosperity to the rural communities 


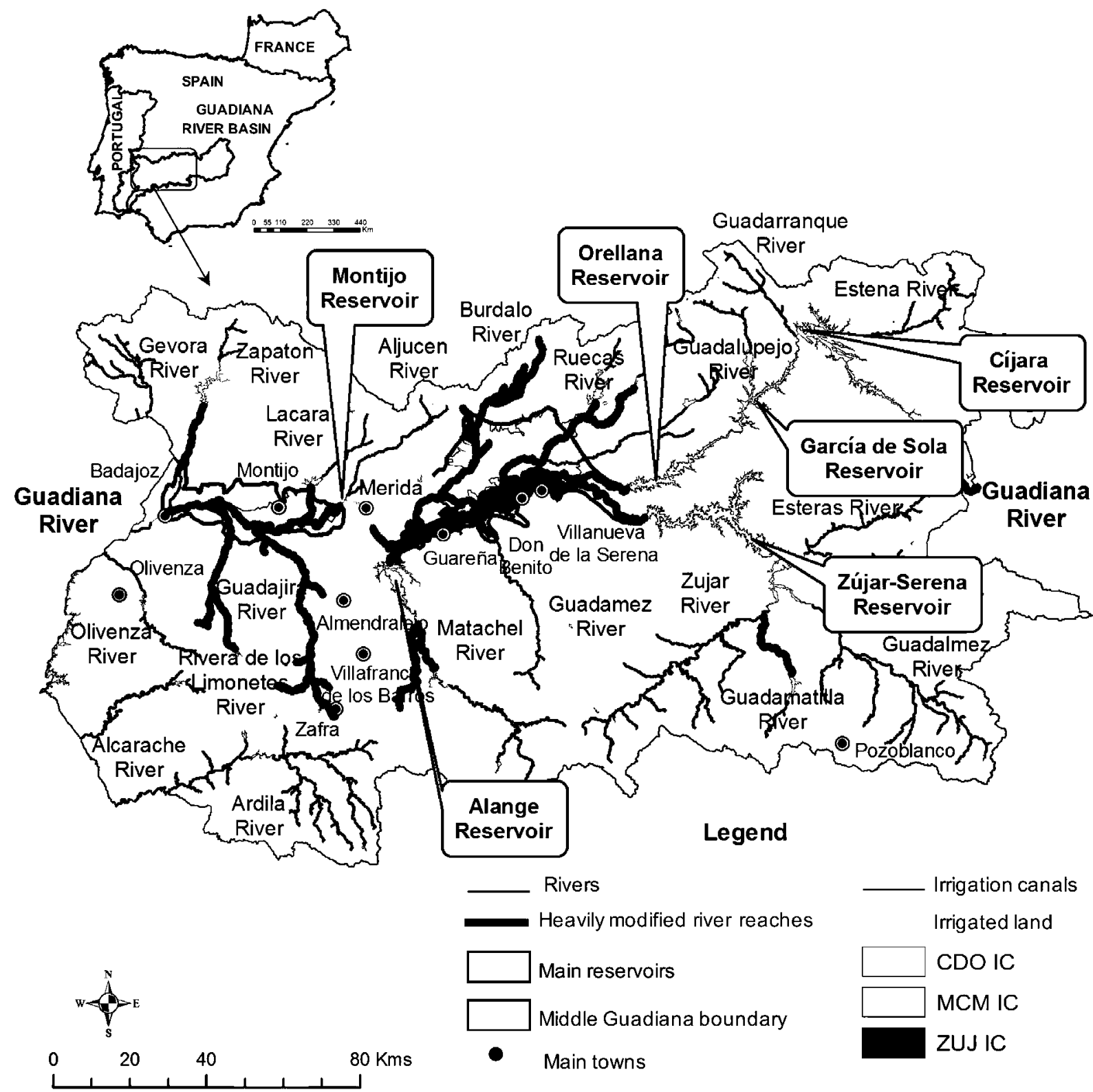

Fig. 1. Geographical location of the study area.

(Krysanova et al., 2010). Yet, it has been accompanied by the alteration of natural flow regimes, an increase in the diffusion of nitrogen pollution, the loss of riparian vegetation, and the degradation of important natural spaces of high ecological value included in the EU Nature 2000 network, such as Sites of Community Importance (SCI) and Special Protection Areas (SPA) (CHG, 2008).

Due to the importance of agricultural pressures, irrigation water management is expected to be crucial to achieving water objectives. In the current context, it seems likely that existing levels of water use for irrigation may be untenable in the future, especially when minimum environmental flows have to be included in future Spanish water planning to protect the status of aquatic ecosystems and ultimately, attain the GES in rivers, as required by the EUWFD (González del Tánago et al., 2012). In consequence, the new Guadiana River Basin Management Plan (GRBMP), as well as other Spanish RBMPs currently being developed and reviewed to comply with the WFD, envisages specific actions targeted to reduce excessive irrigation with the aim of sustaining irrigated agriculture while preserving the aquatic environment. How the implementation of minimum environmental flows will affect agriculture production and the rural livelihoods, and how and to what extent can national water policies contribute to meeting the environmental standards of the EU WFD is still unknown and at the core of controversial policy debates.

This research seeks to shed light on these issues using the emblematic Middle Guadiana basin as a case example to evaluate the potential implications of two key water policy interventions: the implementation of minimum environmental flows (supported by the WFD), and a reduction in the legal amount of water supplied for irrigation purposes (planned measure included in the new GRBMP, still under discussion). Although the hydrologic model was developed at the basin scale to keep the water balance, special attention has been placed on the Irrigation Communities (ICs), which are the institutions responsible for irrigation water management and decision-making at the local level. Out of a total of 12 ICs (of more than 1000 ha), this study focuses on 4 (Canal de Orellana - CDO, Montijo Canal de Montijo - MCM, Zújar - ZUJ, and Tomas Directas del Guadiana - TDG), which account for most of the irrigated agriculture in the region (that is, $72 \%$ of the total irrigated 
surface and $65 \%$ of the farms) and represent the variety of ICs in the study area in terms of location, date of creation, granted water use concessions, source of water, irrigation systems, and crop production. The ICs of CDO (40,400 ha) and ZUJ (21,140 ha) are located upstream on the Middle Guadiana river, MCM (10,600 ha) is situated downstream, and TDG (21,852 ha) is dispersed all along the entire Middle Guadiana river (see Fig. 1). Whereas CDO, ZUJ and MCM extract water from irrigation canals, TDG draws water directly from the river. MCM and CDO, created in the 60's and the 70 's, use large amounts of water to sustain irrigation due, in part, to the poor state of water conveyance systems that results in low efficiency and high operation costs. ZUJ and TDG are characterized by being modern ICs. They date from the 90's and benefit from efficient pressurized irrigation methods (sprinkler and drip), registering lower irrigation water use rates. Farming patterns range from small-scale paddy-based rice farming, mostly concentrated upstream on the right bank of the Middle Guadiana river (in CDO), to large-scale crop-diversified agriculture characterized by a dominance of high value-added crops (such as tomato, olive, and fruit trees), which can be typically found in ZUJ.

\section{Development of an integrated economic-hydrologic modeling framework}

\subsection{Data collection and analysis}

Hydro-economic models, like any other multidisciplinary integrated model, require a vast amount of information and data processing. Table 1 summarizes the type of input data required for the development of the economic and hydrologic models, data sources used, and methodology employed to process all the information.

Relevant empirical information regarding the agricultural sector was obtained from field research. The field work consisted of targeted surveys addressed to ICs and individual farmers. Overall, 5 ICs (CDO, MCM, Mérida - MER, ZUJ, and TDG) and 107 farms comprising 21 municipalities over an area of 4655 ha were surveyed from 2008 to 2010 within the framework of the SCENES project ${ }^{1}$. The information obtained served to enrich the characterization of the irrigation districts and types of farms selected for the study, as well as to obtain the technical coefficients of the economic model.

\subsection{The economic model}

A farm-based regional economic model of constrained optimization was developed to simulate farmers' behavior and predict their response to policy and environmental changes. Farmers' behavior was characterized by a selection of 14 statistically representative farms in terms of the irrigated area, number of farms, soil quality, farming operations, and crop distribution (see Table 2). The selected farm types represent the variety of irrigated production systems in the area of study and extends over seven ICs, eleven municipalities, and three varied agricultural regions. Agricultural census microdata (INE, 1999; INE, 2007; JE, 2007) was used to characterize the different types of farms using cluster analysis as done before by Gómez-Limón and Riesgo (2009), Hardinan et al. (1990), and Köbrich et al. (2003).

The model, written in the General Algebraic Modeling System (GAMS) programming language (Rosenthal, 2012), is formulated as a non-linear mathematical programming model wherein farmers attempt to maximize the expected utility of their net stochastic

\footnotetext{
1 The SCENES project Water Scenarios for Europe and for Neighboring States (2007-2011), funded by the EC 6th Research Framework Program (contract $n^{\circ}$ : 036822), aims to develop a set of comprehensive water scenarios up to 2050 (www. environment.fi/syke/scenes).
}

income, subject to a set of technical, economic and policy constraints. The model runs on a yearly basis and estimates the optimal crop-area distribution by farm type that satisfies all the constraints and gives the highest possible expected utility.

Notwithstanding farms are considered the basic unit of analysis in agriculture, modeling agricultural and natural systems usually requires integrating farm-scale actions with regional-scale approaches (Henseler et al., 2009; Rounsevell et al., 2003). Gómez-Limón and Riesgo (2004) indicates that when decisions are based on the same decision-making criteria (e.g. utility maximization), farm types can be modeled by means of a unique mathematical programming model. In the present study, the economic model maximizes the regional expected utility at the IC level (relevant water management decision unit), by summing all farmers' expected utilities over all farm types that belong to the IC. Farmers' expected utility is calculated as the average net income, minus a variation of that income due to fluctuations in price and production output (see Eq. (1) below). This multi-scale methodological approach facilitates the mobility of resources (land, labor, water) among farms and permits a finer integrated analysis (Blanco-Gutiérrez et al., 2011).

Based on the mean-standard deviation method, the objective function of the model is formulated as follows:

$$
\operatorname{Max} U=\sum_{\mathrm{f}} U_{\mathrm{f}}=\sum_{\mathrm{f}}\left(Z_{\mathrm{f}}-\phi_{\mathrm{f}} \cdot \sigma_{\mathrm{f}}\right)
$$

where $U$ is the regional expected utility at the IC level, $U_{\mathrm{f}}$ is the farmers' expected utility; $Z_{\mathrm{f}}$ is the average net income by farm type $(f), \phi_{\mathrm{f}}$ is the risk aversion coefficient, and $\sigma_{\mathrm{f}}$ is the income standard deviation generated by a set of states of nature defined by climate (yields) and market (prices) variations. To distinguish between variables (endogenously determined) and parameters (exogenously fixed) the former are written in capital letters.

The risk aversion coefficient reveals farmers' attitudes toward risk and induces a well-known trade-off between profitability and riskiness. Risk neutral farmers ( $\phi$ equals zero) only care about maximizing profits, so they generally choose to cultivate high profit, but risky crops. As farmers become more risk averse $(\phi>0)$, they will refuse to accept risk and will choose less-risky crop mixes even if that means sacrificing part of their potential profit. ${ }^{2}$ Numerous theoretical (Friedman and Savage, 1948; Von Neuman and Morgenstern, 1944) and empirical studies (Binswanger, 1980; Chavas, 2004) indicate that farmers typically behave in risk-averse ways and that they behave as utility maximizers rather than profit maximizers only. Ignoring risk-averse behavior may actually lead to unacceptable and unreal results in farm planning models (Hazell and Norton, 1986).

Farm income is defined by the following equation:

$$
\begin{aligned}
Z_{\mathrm{f}}= & \sum_{\mathrm{c}} \sum_{\mathrm{r}} \sum_{\mathrm{d}} \mathrm{gm}_{\mathrm{c}, \mathrm{r}, \mathrm{d}} \cdot X_{\mathrm{c}, \mathrm{r}, \mathrm{d}, \mathrm{f}}+\mathrm{md} \cdot \mathrm{cp} \\
& \cdot \sum_{\mathrm{c}} \sum_{\mathrm{r}} \sum_{\mathrm{d}} \mathrm{sb}_{\mathrm{c}, \mathrm{r}, \mathrm{d}} \cdot \mathrm{X}_{\mathrm{c}, \mathrm{r}, \mathrm{d}, \mathrm{f}}+\mathrm{sfp}_{\mathrm{f}} \cdot \mathrm{md} \cdot \mathrm{numf}_{\mathrm{f}}-\mathrm{cla} \\
& \cdot \sum_{\mathrm{l}, \mathrm{p}} \mathrm{LA}_{\mathrm{l}, \mathrm{p}, \mathrm{f}}-\operatorname{sirrg}_{\mathrm{f}} \cdot(\mathrm{ict}+\mathrm{wtari}+\mathrm{rbf}) \\
& -\mathrm{WUI}_{\mathrm{f}} \cdot(\mathrm{uvc}+\mathrm{cpw})
\end{aligned}
$$

where $X_{c, r, d, f}$ is the set of production activities defined by a combination of crop types (c), irrigation techniques ( $r$ ), soil quality associated to different agricultural regions (d), and farm types ( $\mathrm{f}$;

\footnotetext{
${ }^{2} \phi$ can vary from zero to $1.65(0<\phi<1.65)$. When $\phi=1.65$ then, $U$ identifies the $5 \%$ income fractile, which is the income value that will be exceeded $95 \%$ of the time. In this particular case, farmers will be following the twofold objective of maximizing their profits and minimizing their risks.
} 
Table 1

Input data required for the development of the economic and hydrologic models.

\begin{tabular}{|c|c|c|c|}
\hline Type of data & Source & Format/Methodology & $\begin{array}{l}\text { Used in hydrologic/economic } \\
\text { model }\end{array}$ \\
\hline \multicolumn{4}{|l|}{ Land use data } \\
\hline $\begin{array}{l}\text { Digital Elevation } \\
\text { Model }\end{array}$ & $\begin{array}{l}\text { NASA Shuttle Radar Topographic Mission (SRTM) } \\
\text { from US Geological Survey (USGS) } \\
\text { (www.seamless.usgs.gov) }\end{array}$ & $\begin{array}{l}\text { 90-m resolution elevation } \\
\text { data processed in GIS }\end{array}$ & Hydrologic model \\
\hline Land cover & $\begin{array}{l}\text { CORINE Land Cover database from the National } \\
\text { Geographic Institute of Spain (IGN, 2004) }\end{array}$ & $\begin{array}{l}\text { Digital maps ( } 1 / 100,000 \text { scale }) \\
\text { processed in GIS }\end{array}$ & Hydrologic model \\
\hline \multicolumn{4}{|l|}{ Climate data } \\
\hline $\begin{array}{l}\text { Precipitation, temp., } \\
\text { relative humidity, latitude }\end{array}$ & $\begin{array}{l}\text { CRU TS } 2.1 \text { Global Climate Database from CGIAR } \\
\text { (Mitchell and Jones, 2005) } \\
\text { Spanish State Meteorological Agency (AEMET, 2004) }\end{array}$ & $\begin{array}{l}0.5 \text {-degree resolution. } \\
\text { Monthly-time series } \\
\text { processed in GIS }\end{array}$ & Hydrologic model \\
\hline \multicolumn{4}{|l|}{ Water supply data } \\
\hline $\begin{array}{l}\text { Watersheds areas, river } \\
\text { flows, infrastructure operations, } \\
\text { streamgages }\end{array}$ & $\begin{array}{l}\text { Guadiana River Basin Authority (GRBA) } \\
\text { (www.chguadiana.es) } \\
\text { Integrated Water Information systems } \\
\text { of Spain (SIA) (www.marm.es) } \\
\text { Automatic System of Hydrologic Information } \\
\text { (SAIH) (www.saihguadiana.com) }\end{array}$ & $\begin{array}{l}\text { Shapefiles processed in GIS } \\
\text { Data records processed } \\
\text { in Excel \& CSV }\end{array}$ & Hydrologic model \\
\hline \multicolumn{4}{|l|}{ Water demand data } \\
\hline $\begin{array}{l}\text { Agricultural sector } \\
\text { (characterization of Irrigation } \\
\text { Communities, farm types) }\end{array}$ & $\begin{array}{l}\text { Spanish Ministry of Environment and Rural } \\
\text { and Marine Affairs (Web Map Service) } \\
\text { Regional Department of Agriculture } \\
\text { of Extremadura (JE, 2007) } \\
\text { Spanish National Statistics Institute } \\
\text { (INE) (INE, 1999; INE, 2007) } \\
\text { Field work }\end{array}$ & $\begin{array}{l}\text { Digitalization in GIS } \\
\text { Cluster analysis in Excel } \\
\text { Text files }\end{array}$ & $\begin{array}{l}\text { Economic \& hydrologic } \\
\text { models }\end{array}$ \\
\hline \multicolumn{4}{|l|}{ Urban sector } \\
\hline Cities, population & $\begin{array}{l}\text { Spanish Spatial Data Infrastructure (IDEE) } \\
\text { (www.idee.es) } \\
\text { Municipal census from the Spanish National } \\
\text { Statistics Institute (INE) (www.ine.es) }\end{array}$ & $\begin{array}{l}\text { Digitalization in GIS } \\
\text { Excel files }\end{array}$ & Hydrologic model \\
\hline Water use rates & $\begin{array}{l}\text { Guadiana River Basin Authority (GRBA) } \\
\text { (www.chguadiana.es) }\end{array}$ & Excel files & Hydrologic model \\
\hline \multicolumn{4}{|c|}{ ( } \\
\hline $\begin{array}{l}\text { Technical itineraries (irrigation } \\
\text { schedule, farming operations) }\end{array}$ & $\begin{array}{l}\text { Spanish Ministry of Environment and Rural } \\
\text { and Marine Affairs (MAPA, 2005) } \\
\text { Irrigation Advisory Service of Extremadura } \\
\text { (REDAREX) (www.aym.juntaex.es) } \\
\text { Field work }\end{array}$ & Excel, text files & $\begin{array}{l}\text { Economic \& hydrologic } \\
\text { models }\end{array}$ \\
\hline $\begin{array}{l}\text { Production costs, yields, crop prices, } \\
\text { subsidies, water needs, labor use }\end{array}$ & $\begin{array}{l}\text { Guadiana River Basin Authority (CHG, 2008) } \\
\text { Spanish Ministry of Environment and Rural } \\
\text { and Marine Affairs (MAPA, 2007) } \\
\text { Regional Department of Agriculture } \\
\text { of Extremadura (JE, 2007) } \\
\text { TEPRO (agricultural consultancy group) } \\
\text { (www.tepro.es) } \\
\text { Field work }\end{array}$ & Excel, text files & Economic model \\
\hline \multicolumn{4}{|l|}{ Agro-hydrological parameters } \\
\hline $\begin{array}{l}\text { Crop coefficients, soil water capacity, } \\
\text { conductivity, flow direction }\end{array}$ & $\begin{array}{l}\text { Spanish Agroclimatic Information System } \\
\text { (SIAR) (www.mapa.es/siar/) } \\
\text { Literature review: Allen et al. (1998); } \\
\text { CCU-SEI (2009);Young et al. (2009) }\end{array}$ & Excel, text files & Hydrologic model \\
\hline
\end{tabular}

gm $_{c, r, d}$ is the gross margin of different production activities (calculated as revenue, crop prices multiplied by yields, minus the cost of production); $\mathrm{sb}_{\mathrm{c}, \mathrm{r}, \mathrm{d}}$ are the production-based subsidies given to certain crops of the CAP; md is the modulation rate (reduction applied to farmers' direct payments to support CAP rural development programs); $\mathrm{cp}$ is the coupling rate (percentage of direct CAP payments that is associated with current crop production); $\mathrm{sfp}_{\mathrm{f}}$ is the Single Farm Payment (direct CAP payment per farm based on historical production patterns); numf $f_{\mathrm{f}}$ is the number of farm types $\mathrm{f}$; cla is the cost of farm labor (opportunity cost of family labor and the wage for hired labor); $L A_{1, p, f}$ is the farm labor used by type of labor force (l), season (p) and farm (f); $\operatorname{sirrg}_{i, f}$ is the irrigated surface; ict is the water use tariff paid to the IC; wtarif is the water use tariff paid to the Guadiana River Basin Authority (GRBA); rbf is the river basin fee paid to cover the state-financed infrastructure works carried out in the basin; WUI $_{\mathrm{f}}$ is the volume of water used for irrigation in a specific farm (f); uvc is the uniform volumetric charge; and $\mathrm{cpw}_{\mathrm{f}}$ is the cost of pumping water.

The standard deviation of the income distribution is calculated as follows:

$\sigma_{\mathrm{f}}=\left[\left(\sum_{\mathrm{sn}} \sum_{\mathrm{sm}} Z_{\mathrm{sn}, \mathrm{sm}, \mathrm{f}}-Z_{\mathrm{f}}\right)^{2} / n\right]^{1 / 2}$

where $Z_{\mathrm{sn}, \mathrm{sm}, \mathrm{f}}$ is the random income, $Z_{\mathrm{f}}$ is the average net income, $\mathrm{sn}$ are the states of nature, sm are the states of market, and $n$ is the combination of different states of nature $(n=100)$. Farm income is assumed to be normally distributed.

The objective function is subjected to the following constraints:

-Land constraints, which limit the total area of cultivated land

$\left(\right.$ surf $_{\mathrm{f}}$ ) (Eq. (4)); and the potential area under irrigation 
Table 2

Representative farm types in the Middle Guadiana basin.

\begin{tabular}{|c|c|c|c|c|c|}
\hline $\begin{array}{l}\text { Farm } \\
\text { type }\end{array}$ & $\begin{array}{l}\text { IC } \\
\text { Code }^{a}\end{array}$ & $\begin{array}{l}\text { Farm } \\
\text { size (ha) }\end{array}$ & $\begin{array}{l}\text { Weight\% } \\
\text { in the IC (\%) }\end{array}$ & $\begin{array}{l}\text { Area irrigated } \\
\text { under PIS }(\%)\end{array}$ & Cropping pattern \\
\hline $\mathbf{F}_{1}$ & CDO & 35 & 54 & 20 & Rice $(42 \%)$,Maize (25\%),Tomato (20\%),Peach (10\%),Set-aside (3\%) \\
\hline $\mathrm{F}_{2}$ & & 25 & 25 & 0 & Rice $(100 \%)$ \\
\hline$F_{3}$ & & 15 & 21 & 30 & Maize (46\%), Rice (25\%), Tomato (25\%), Set-aside (4\%) \\
\hline $\mathrm{F}_{4}$ & MCM & 30 & 76 & 20 & Maize $(41 \%)$,Tomato (25\%),Peach $(20 \%)$, Olive $(5 \%)$, Wheat $(5 \%)$,Set-aside $(4 \%)$ \\
\hline $\mathrm{F}_{5}$ & & 10 & 24 & 10 & Tomato (60\%), Maize (36\%), Set-aside $(4 \%)$ \\
\hline$F_{6}$ & MER & 100 & 100 & 30 & Peach (30\%),Maize (27\%),Tomato (20\%), Olive (20\%), Set-aside (3\%) \\
\hline $\mathrm{F}_{7}$ & TDG & 90 & 53 & 60 & Maize ( $40 \%)$,Tomato (20\%),Peach (15\%),Olive (10\%),Melon (10\%),Set-aside (5\%) \\
\hline$F_{8}$ & & 20 & 47 & 35 & Maize (54\%),Rice (25\%),Tomato (10\%),Set-aside (6\%),Peach (5\%) \\
\hline $\mathrm{F}_{9}$ & TLR & 75 & 49 & 50 & Maize (53\%), Wheat (15\%), Tomato (10\%),Plum (10\%),Set-aside (7\%),Vineyard (5\%) \\
\hline$F_{10}$ & & 25 & 51 & 40 & Maize $(50 \%)$, Wheat $(22 \%)$,Tomato $(10 \%)$,Set-aside $(8 \%)$ \\
\hline $\mathrm{F}_{11}$ & VAS & 40 & 100 & 20 & Rice $(50 \%)$, Wheat $(24 \%)$,Maize (16\%),Set-aside $(10 \%)$ \\
\hline $\mathrm{F}_{12}$ & ZUJ & 60 & 49 & 90 & Maize $(49 \%)$,Tomato $(23 \%)$,Olive $(15 \%)$, Rice $(7 \%)$, Set-aside $(6 \%)$ \\
\hline$F_{13}$ & & 35 & 19 & 60 & Peach $(40 \%)$, Plum $(20 \%)$, Rice $(20 \%)$,Maize $(15 \%)$, Tomato $(5 \%)$,Set-aside $(2 \%)$ \\
\hline$F_{14}$ & & 25 & 32 & 100 & Maize ( $40 \%)$,Tomato $(35 \%)$,olive (20\%),Set-aside $(5 \%)$ \\
\hline
\end{tabular}

a IC Code: CDO-Canal de Orellana, MCM-Montijo Canal de Montijo, MER-Mêrida, TDG-Tomas Directas del Guadiana, TLR-Talavera La Real; VAS-Vegas Altas, ZUJ-Zújar

b PIS: Pressurized Irrigation Systems (drip and sprinkler irrigation)

$\left(\operatorname{sirrg}_{f}\right)$, where ri refer to surface, sprinkler or drip irrigation (Eq. (5)):

$\sum_{c, \mathrm{r}, \mathrm{d}} X_{c, \mathrm{r}, \mathrm{d}, \mathrm{f}} \leq \operatorname{surf}_{\mathrm{r}}$

$\sum_{\mathrm{c}} \sum_{\mathrm{ri}} \sum_{\mathrm{d}} X_{\mathrm{c}, \mathrm{ri}, \mathrm{d}, \mathrm{f}} \leq \operatorname{sirrg}_{\mathrm{f}}$

-Labor constraints, which limit the seasonal labor requirements $\left(\mathrm{r}_{\mathrm{c}, \mathrm{r}, \mathrm{p}}\right)$ to the total available agricultural labor (family, fla $\mathrm{a}_{\mathrm{p}, \mathrm{f}}$, and hired labor, $\mathrm{HL}_{\mathrm{p}, \mathrm{f}}$ ) (Eq. (6)):

$\sum_{c, \mathrm{r}, \mathrm{d}} \operatorname{lr}_{\mathrm{c}, \mathrm{r}, \mathrm{p}} \cdot X_{\mathrm{c}, \mathrm{r}, \mathrm{d}, \mathrm{f}}=\sum_{\mathrm{l}} \mathrm{LA}_{\mathrm{l}, \mathrm{p}, \mathrm{f}} \leq \mathrm{fla}_{\mathrm{p}, \mathrm{f}}+\mathrm{HL}_{\mathrm{p}, \mathrm{f}}$

-Water constraints indicate that the total amount of water used for irrigation at farm level (WUI $)$ cannot exceed the available water supply (wsupf) (Eq. (7)):

$\sum_{c, r i, d} \operatorname{niwr}_{c, d} \cdot X_{c, r i, d, f} / h_{r i}=$ WUI $_{\mathrm{f}} \leq$ watera $_{\mathrm{f}} \cdot \operatorname{sirrg}_{\mathrm{f}} \cdot H=$ wsup $_{\mathrm{f}}$

$\mathrm{WUI}_{\mathrm{f}}$ is determined by the model based on the net crop irrigation water requirements ( niwr $_{\mathrm{c}, \mathrm{d}}$ ), that is the amount of irrigation water required to meet crops' evapotranspiration needs, farmers' cropping pattern $\left(X_{c, r i, d, f}\right)$, and the performance of irrigation systems (on-farm irrigation efficiency, $h_{\mathrm{ri}}$ ). In turn, irrigation water supply ( wsup $_{\mathrm{f}}$ ) can be restricted by legal and physical limits, expressed through the term watera (amount of irrigation water made available at the farm level), and lost during transport through irrigation channels (conveyance efficiency, $H$ ). According to the applicable water legislation (MMA, 2001), farmers are provided with water rights (legal permissions to abstract and use a predefined quantity of water for irrigation), calculated by dividing the volume of water given in concession to a specific IC by its total irrigated area. Consequently, all the irrigators belonging to the same IC benefit from equal water rights (watera $\mathbf{a}_{f}$ ), regardless of the type of crops they actually grow.

-Policy constraints, such that the requirement to set-aside $\left(X_{\mathrm{sa}, \mathrm{r}, \mathrm{d}, \mathrm{f}}\right)$ a minimum $(\mathrm{smin})$ and maximum (smax) of the COP (cereals, oilseeds and proteins) growing area $\left(X_{\text {cop,r,d,f }}\right)$ as a prerequisite to receive CAP direct payments (Eq. (8)): $\operatorname{smin} \cdot \sum_{\mathrm{cop}, \mathrm{r}, \mathrm{d}} X_{\mathrm{cop}, \mathrm{r}, \mathrm{d}, \mathrm{f}} \leq \sum_{\mathrm{r}, \mathrm{d}} X_{\mathrm{sa}, \mathrm{r}, \mathrm{d}, \mathrm{f}} \leq \operatorname{smax} \cdot \sum_{\mathrm{cop}, \mathrm{r}, \mathrm{d}} X_{\mathrm{cop}, \mathrm{r}, \mathrm{d}, \mathrm{f}}$

The economic model was calibrated using the risk-aversion coefficient $(\Phi)$ before being used for policy simulations. The Percentage Absolute Deviation (PAD) statistical parameter was used to measure the accuracy of the economic model in replicating the initial crop area distribution for the agronomic year 2006. According to this parameter, ${ }^{3}$ the error scores were calculated as the sum of absolute percentage differences between observed and simulated crop areas by farm type. The risk aversion coefficients estimated in this study ranged between $0.9\left(\right.$ farm $\mathrm{F}_{4}$ ) and 1.4 (farm $F_{8}$ ). These coefficients ensured the robustness and accuracy of the model by providing PAD values that varied from 7 (farm $F_{5}$ ) to 19 (farm $F_{3}$ ) (Hazell and Norton, 1986; Kanellopoulos et al., 2010). The model results were validated for the base year 2007, once the economic model was coupled to the hydrologic model.

\subsection{The hydrologic model}

The hydrologic model WEAP ('Water Evaluation And Planning' system) was developed and applied to the Middle Guadiana basin to explore the behavior of hydrologic systems, particularly in irrigated catchments. WEAP is an object-oriented computer modeling package developed by the Stockholm Environment Institute's US Center that simulates both the biophysical and engineered components of water systems, providing a comprehensive view of the many factors affecting water resource decision-making (Sieber and Purkey, 2011; Yates et al., 2005).

The Middle Guadiana basin WEAP application comprises all pertinent demand and supply elements and their inter-relations. Elements include major rivers (the Guadiana river and 8 tributaries); major irrigation channels (namely, Orellana, Zújar, Montijo, and Lobón); 10 major reservoirs with a total storage capacity of $7500 \mathrm{Mm}^{3}$ ( $95 \%$ of the total storage capacity in the Middle Guadiana basin); and most important water demand sites (11 group of cities sharing water services and costs, all ICs). In addition, the entire basin was characterized by a contiguous set of 15 catchments divided in fractional sections that represent areas of similar land use classes (forest, semi-natural areas, pasture, non-irrigated agricultural land, and irrigated agricultural land, depicted by the

\footnotetext{
${ }^{3} \mathrm{PAD}_{f}=\sum_{c}^{n}{ }_{n}\left|\overline{X_{c}}-X_{c}\right| \cdot 100 / \sum_{c}^{n}{ }_{n} \overline{X_{c}} ;$ f: farm type; c: crop indices: $\overline{X_{c}}$ : observed surface (\%); $X_{c}$ : simulated surface (\%).The best calibration is reached when PAD is
} close to 0 
Table 3

Characterization of the catchment units in WEAP.

\begin{tabular}{|c|c|c|c|c|c|c|c|}
\hline \multirow[t]{2}{*}{ Catchments } & \multirow[t]{2}{*}{$\mathrm{N}^{\circ}$ of $\mathrm{lCs}$} & \multicolumn{5}{|c|}{ Land use area $\left(\mathrm{km}^{2}\right)$} & \multirow[t]{2}{*}{ Total $\left(\mathrm{km}^{2}\right)$} \\
\hline & & Forests & Seminatural land & Pastures & Non-irrigated & Irrigated & \\
\hline 1. Albuera de Nogales & $3^{a}$ & 41 & 262 & 292 & 1581 & 230 & 2407 \\
\hline 2. Aljucen & 0 & 9 & 28 & 109 & 27 & 0 & 173 \\
\hline 3. Cijara & 0 & 629 & 1554 & 27 & 1107 & 0 & 3318 \\
\hline 4. García de Sola & 0 & 222 & 306 & 215 & 82 & 0 & 825 \\
\hline 5. Guadalupejo & 0 & 40 & 95 & 50 & 45 & 0 & 230 \\
\hline 6. Guadarranque & 0 & 77 & 128 & 41 & 12 & 0 & 258 \\
\hline 7. Mérida & $5^{b}$ & 285 & 928 & 849 & 1434 & 794 & 4290 \\
\hline 8. Puente de palmas & $4^{\mathrm{c}}$ & 46 & 156 & 404 & 543 & 234 & 1383 \\
\hline 9. Villanueva Serena & $1^{\mathrm{d}}$ & 32 & 201 & 140 & 350 & 38 & 761 \\
\hline 10. Gêvora & 0 & 156 & 691 & 749 & 145 & 0 & 1741 \\
\hline 11. Lácara & 0 & 44 & 55 & 162 & 46 & 0 & 307 \\
\hline 12. Matachel & 0 & 112 & 400 & 186 & 1784 & 0 & 2482 \\
\hline 13. Orellana & 0 & 115 & 387 & 132 & 110 & 0 & 744 \\
\hline 14. Züjar-Serena & 0 & 444 & 2184 & 1680 & 3145 & 0 & 7452 \\
\hline 15. Zújar-Villanueva Serena & 0 & 17 & 415 & 73 & 445 & 0 & 949 \\
\hline TOTAL & 12 & 2269 & 7789 & 5111 & 10,855 & 1296 & 27,319 \\
\hline
\end{tabular}

ICs included in the economic model: (a) TLR, MCM, MER; ${ }^{(b)} \mathrm{CDO}, \mathrm{ZUJ}, \mathrm{TDG}\left(\mathrm{F}_{8}\right) ;{ }^{\left({ }^{(c)} \mathrm{TDG}\right.}\left(\mathrm{F}_{7}\right)$; ${ }^{(\mathrm{d})} \mathrm{VAS}$.

following crops: wheat, maize, rice, melon, tomato, olive, vineyard, peach, and plum) (see Table 3 ). Following recent WEAP applications (Purkey et al., 2008; Young et al., 2009), catchment units were delineated, using a $90 \mathrm{~m}$ SRTM Digital Elevation Model and watershed pour points, and populated with spatially distributed climate and land cover data obtained from IGN (2004) and Mitchell and Jones (2005).

Catchment functioning is simulated through the soil moisture method in WEAP, where a water mass balance is computed for each catchment unit and fractional land use area (see Yates et al., 2005, 2009 for a detailed discussion of the model algorithms). In brief, this method considers one dimensional, two-compartment (or 'bucket') soil moisture scheme to calculate irrigation, evapotranspiration, surface runoff, sub-surface runoff (interflow), percolation, and base flow, based on a set of agronomic and hydrologic parameters: crop coefficients for several stages of the plan growth (initial, development, middle, and late) $\left(K_{\mathrm{c}}\right)$; runoff-resistance factor (Rrf); preferred flow direction (Fd); effective water-holding capacity of the upper and deep soil layers (Swc and Dwc); hydraulic conductivity rates of the upper and deep soil layers $\left(K_{1}\right.$ and $\left.K_{2}\right)$; relative storage of the upper and deep soil layers $\left(Z_{1}\right.$ and $Z_{2}$ ).

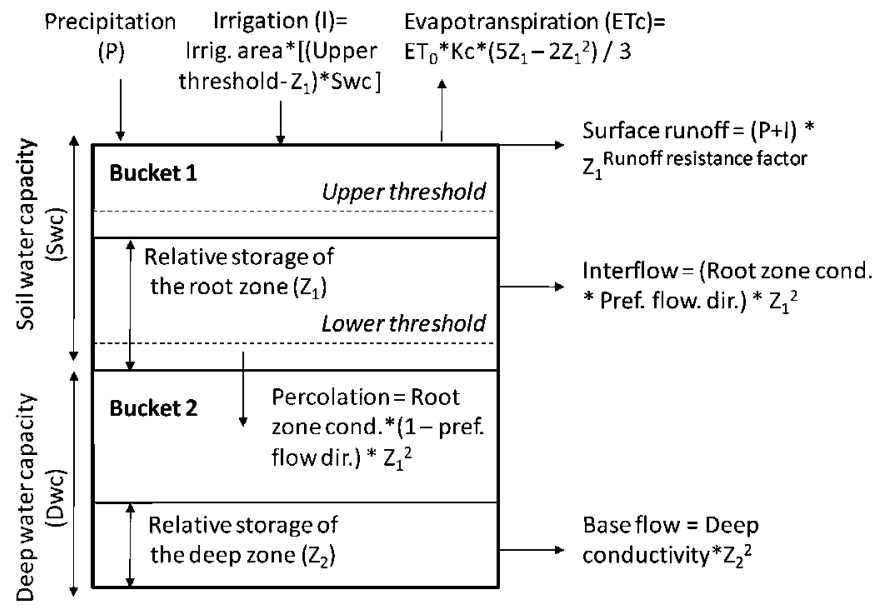

Source: Adapted from Yates et al. (2005)

Fig. 2. Two-bucket soil moisture accounting scheme in WEAP.
Fig. 2 shows a schematic representation of the soil moisture method in WEAP.

Irrigation water is applied when evapotranspiration requirements cannot be satisfied by natural precipitation and stored soil water. The amount and timing of irrigation for a specific crop is estimated using upper and lower thresholds for soil moisture content (see Fig. 2), which determine the maximum amount of water that a crop can extract. When soil moisture drops below the lower threshold it generates an irrigation demand that ceases when soil moisture reaches the upper threshold. In addition, WEAP includes a ponding routing that represents flooding practices for rice cultivation. A set of parameters (flooding season, maximum, minimum and target depth of water above ground, release requirements) controls the timing and magnitude of water deliveries in order to maintain healthy plan growth. The cropping patterns used on farms determine farmers' irrigation water requirements and, consequently, irrigation water demand at the IC level. Domestic water demand for cities is calculated by taking into account the number of people living the cities (population) and the average residential water use per person.

Based on the basic principle of water accounting (inflows equal outflows), WEAP computes a mass balance for water at every site and every link in the system on a monthly time step. Because of the relatively long time scale (monthly), all water entering the system in a given month is available for other demand site after use within the same month. Simultaneously, WEAP uses a linear programming model to solve the water allocation problem. It employs a prioritybased optimization algorithm to maximize the satisfaction of all water demand sites subject to water use priorities, supply preferences, mass balances calculations, and other constraints (e.g. storage and conveyance capacities) (Sieber and Purkey, 2011). According to the Spanish water law (MMA, 2001), the use of water for domestic purposes has the highest priority. Therefore, in cases where there is not enough water to satisfy all demands, cities are allocated water before ICs. Likewise, in times of shortage, water shortfalls are equally shared among sites with the same priority (e.g. between cities, all ranked 1 , and between ICs, all ranked 2). Minimum environmental flows are not considered a water use, but a constraint imposed prior to any other use. ${ }^{4}$ Accordingly,

\footnotetext{
${ }^{4}$ They are defined as a quantity of water in a river that is protected from extraction to maintain the fish assemblages that naturally inhabit or would inhabit the river, and its riparian vegetation ( $\mathrm{CHG}, 2008)$
} 
minimum flow requirements have been modeled through the imposition of top priority fixed allocations to specific places in the Middle Guadiana river system.

The hydrologic model was calibrated by comparing simulations with stream flows records observed at 12 gauging stations for the period January 1974 to December 1990 . The calibration was performed using the agro-hydrological parameters as calibration factors to modify the seasonal and inter-annual behavior of key hydrological processes (surface runoff, interflow and base flow). Table 4 shows the average values of the soil parameters used to calibrate the hydrologic model.

The accuracy of the model at predicting stream flows was quantified using reliable goodness-of-fit statistics, such as the Bias and the Nash-Sutcliffe efficiency index ${ }^{5}$ (Nash and Sutcliffe, 1970). Values of the Bias ranged between $-12 \%$ and $+15 \%$ with an average of $+2 \%$. The Nash-Sutcliffe parameter varied from 0.73 to 0.88 with an average of 0.81 .

\subsection{Modeling integration}

The integration of the economic and hydrologic models is made, empirically, by replicating the different irrigation demands and future scenarios in both models, and technically, by means of a programming interface developed using Visual Basic that permits running the models externally and facilitates the exchange of data between the two models.

Following Kragt et al. (2011), the economic and the hydrologic models were developed in a synchronized way to ensure proper communication of data between them. This is particularly important in hydro-economic models where the socio-economic and the hydrologic components usually operate at different spatial and temporal resolutions. To facilitate scale bridging, the selected farm types used to represent farmers' behavior in the economic model were mapped on the specific geographical sites of the ICs located in definite irrigated catchments using the schematic view in WEAP. This permits to up-scale farm-based results obtained from the economic model to the basin' level and similarly, to down-scale spatially distributed water observations captured by the hydrologic model at the basin level to the farm level.

The interaction of socio-economic and hydrologic processes occurs explicitly in a linking scheme, as shown in Fig. 3.

As described in Mainuddin et al. (2007) and Maneta et al. (2009), the economic and hydrologic models are subsequently run so that the output data from one of the models is entered as input data into the other model. The economic model determines the optimal cropping pattern that maximizes farmers' expected utility. The hydrologic model then operates using this information to simulate water mass balances and optimize the allocation of water resources in the basin. Monthly data generated by the hydrologic model is aggregated to the annual time scale to provide the economic model (through Eq. (7)) with updated information on crop irrigation water requirements and irrigation water availability. The amount of irrigation water made available at the farm level corresponds to the volume of water allocated to the IC to which farmers belong divided by the total irrigated area, as established by law (MMA, 2001). This process is run iteratively until changes in cropped areas permit the hydrologic system to fulfill irrigation requirements for optimal crop production.

\footnotetext{
BIAS $=100[(\overline{Q S}-\overline{Q o}) / \overline{Q o}] ; N A S H=1-\left[\sum_{i}^{n}{ }_{1}\left(Q_{S, i}-Q_{0, i}\right)^{2} / \sum_{i}^{n}{ }_{1}\left(Q_{0, i}-\overline{Q_{0}}\right)^{2}\right]$,
} where $\overline{Q_{S}}$ and $\overline{Q_{0}}$ are the average simulated and observed flow rates, and $Q_{5, i}$ and $Q_{0, i}$ are simulated and observed flow rates for each time step $(i)$ and $(n)$. The best calibration is reached when Bias is close to 0 and Nash is close to 1.
Table 4

Applied soil parameters to calibrate the hydrologic model WEAP.

\begin{tabular}{|c|c|c|c|c|c|}
\hline \multirow{2}{*}{$\begin{array}{l}\text { Agro-hydrological } \\
\text { parameters }\end{array}$} & \multirow[t]{2}{*}{ Code } & \multicolumn{4}{|l|}{ Land class } \\
\hline & & $\begin{array}{l}\text { Agricultural } \\
\text { land }\end{array}$ & Forest & Pasture & $\begin{array}{l}\text { Seminatural } \\
\text { area }\end{array}$ \\
\hline Crop coefficient & $\mathrm{K}_{\mathrm{c}}$ & 1.17 & 1 & 0.9 & 0.7 \\
\hline $\begin{array}{l}\text { Runoff resistance } \\
\text { factor }\end{array}$ & Rrf & 4.5 & 5 & 3 & 2 \\
\hline Flow direction & $\mathrm{Fd}$ & 0.5 & 0.5 & 0.5 & 0.5 \\
\hline $\begin{array}{l}\text { Root zone water } \\
\text { capacity (mm) }\end{array}$ & Swc & 850 & 750 & 950 & 150 \\
\hline $\begin{array}{l}\text { Root zone hydraulic } \\
\text { conductivity } \\
\text { (mm/month) }\end{array}$ & $\mathrm{K}_{1}$ & 150 & 150 & 150 & 150 \\
\hline $\begin{array}{l}\text { Relative storage } \\
\text { of the root zone (\%) }\end{array}$ & $\mathrm{Z}_{1}$ & 30 & 30 & 30 & 30 \\
\hline $\begin{array}{l}\text { Deep water } \\
\text { capacity (mm) }\end{array}$ & Dwc & 1000 & 1000 & 1000 & 1000 \\
\hline $\begin{array}{l}\text { Deep hydraulic } \\
\text { conductivity } \\
\text { (mm/month) }\end{array}$ & $\mathrm{K}_{2}$ & 20 & 20 & 20 & 20 \\
\hline $\begin{array}{l}\text { Relative storage } \\
\text { of the deep zone (\%) }\end{array}$ & $\mathrm{Z}_{2}$ & 40 & 40 & 40 & 40 \\
\hline
\end{tabular}

Since the models operate in a stand-alone mode, the loop iteration can start from the economic or the hydrologic model, either way. The hydrologic model explicitly contains the spatial and temporal arrangement of landscape features. Thus, variables with a strong spatial and temporal dependency, such as ecohydrological and weather conditions, are better specified and analyzed by the hydrologic model, which would constitute the starting point of the analysis. In turn, changes in the socio-institutional, economic and political context are better captured by the economic model and hence, they are analyzed running the economic model first.

\section{Scenario simulation}

The analysis starts in the base year 2007 and goes up to 2015, which corresponds to the deadline established by the WFD for achieving environmental goals. This study offers a thorough description of the present and potential future situation according to three scenarios:

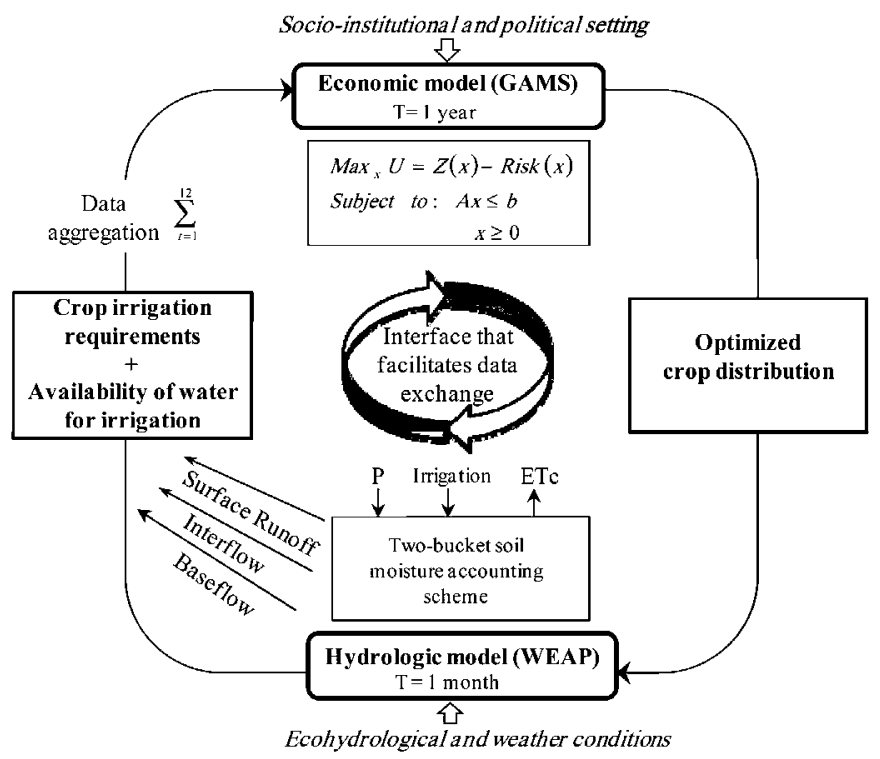

Fig. 3. Schematic representation of the integrated economic-hydrologic modeling framework. 
Table 5

Environmental flow requirements of selected river reaches simulated in WEAP.

\begin{tabular}{|c|c|c|c|c|c|c|c|c|c|c|c|c|c|c|}
\hline \multirow[t]{3}{*}{ River reach } & \multirow{3}{*}{$\begin{array}{l}\text { Mean annual } \\
\text { flow }\left(\mathrm{mm}^{3} / \mathrm{y}\right)\end{array}$} & \multicolumn{13}{|c|}{ Minimum environmental flows } \\
\hline & & \multirow{2}{*}{$\begin{array}{l}\% \text { of the mean } \\
\text { annual flow }\end{array}$} & \multicolumn{12}{|c|}{ Monthly $\left(\mathrm{m}^{3} / \mathrm{s}\right)$} \\
\hline & & & Oct & Nov & Dec & Jan & Feb & Mar & Apr & May & Jun & Jul & Aug & Sep \\
\hline Guadiana IV & 170 & 3.5 & 0.47 & 0.52 & 0.91 & 0.85 & 0.70 & 0.64 & 0.63 & 0.57 & 0.26 & 0.08 & 0.06 & 0.14 \\
\hline Guadiana VI & 3728 & 9.0 & 7.54 & 9.46 & 14.31 & 14.16 & 11.55 & 9.12 & 8.19 & 6.10 & 2.85 & 0.78 & 0.68 & 2.16 \\
\hline Guadiana V & 5229 & 4.1 & 7.05 & 8.81 & 13.47 & 13.34 & 10.86 & 8.68 & 7.88 & 5.97 & 2.78 & 0.78 & 0.67 & 2.08 \\
\hline Guadamatilla & 873 & 6.1 & 0.51 & 0.58 & 1.98 & 2.70 & 2.84 & 1.78 & 0.96 & 0.30 & 0.05 & 0.01 & 0.00 & 0.02 \\
\hline Zujarll & 5872 & 13.9 & 14.05 & 24.68 & 26.29 & 52.18 & 75.69 & 38.67 & 24.00 & 9.76 & 1.96 & 0.12 & 0.18 & 1.90 \\
\hline MatachellI & 1156 & 9.0 & 1.57 & 3.15 & 6.41 & 8.04 & 9.01 & 6.05 & 4.25 & 1.05 & 0.18 & 0.00 & 0.01 & 0.12 \\
\hline MatachellIl & 3237 & 4.6 & 2.20 & 4.72 & 9.30 & 11.67 & 13.10 & 8.70 & 5.90 & 1.42 & 0.26 & 0.01 & 0.01 & 0.17 \\
\hline Lacara & 385 & 12.4 & 1.16 & 2.27 & 3.17 & 4.18 & 5.06 & 2.95 & 1.34 & 0.38 & 0.04 & 0.00 & 0.00 & 0.02 \\
\hline Zapatonll & 1234 & 9.1 & 2.90 & 4.27 & 8.47 & 8.56 & 9.53 & 5.76 & 2.45 & 0.74 & 0.07 & 0.00 & 0.00 & 0.08 \\
\hline Rivera Limonetes & 212 & 11.9 & 0.80 & 1.08 & 2.06 & 1.44 & 2.63 & 0.97 & 0.78 & 0.25 & 0.05 & 0.00 & 0.00 & 0.08 \\
\hline
\end{tabular}

Source: Own elaboration based on CHG (2009).

-Scenario 1: Business-As-Usual (BAU) scenario. It is defined as the baseline scenario in which recent trends continue during the time frame considered (2007-2015). It has been assumed that the current water concession system continue to operate until 2015 as it does at present. In the BAU scenario, CDO farmers benefits from an annual water use right of $10,900 \mathrm{~m}^{3} /$ ha, MCM of $8500 \mathrm{~m}^{3}$ /ha, ZUJ of $7500 \mathrm{~m}^{3} / \mathrm{ha}$, and TDG of $8000 \mathrm{~m}^{3} / \mathrm{ha}$.

-Scenario 2: EU policy-driven scenario. Minimum flow requirements are implemented to obtain a GES in rivers as required by the EUWFD. The GES in rivers is only estimated with respect to hydrologic regime. Other ecological indicators have been disregarded in this analysis. Out of a total of 19 river reaches declared 'at risk' (heavily modified) by the Guadiana River Basin Authority, the present study focuses on 10 river reaches dispersed all along the Middle Guadiana river and its main tributaries: Zujar, Matachel, Lacara, Zapaton, and Rivera de los Limonetes. The remaining river reaches are located on minor tributaries to the Guadiana river that were not represented in the stylized Middle Guadiana WEAP application. Table 5 shows the minimum river flow requirements simulated in the study area at a monthly time scale using WEAP.

As seen in Table 5 , minimum flows represent about $4-14 \%$ of the average annual flow for the selected river reaches. A detailed description of the methods used by the GRBA to determine ecological flows can be found in CHG (2009).

- Scenario 3: National policy-driven scenario. The legal amount of water annually delivered to the different ICs (water concessions) is restricted to strike a balance between agricultural and environmental water uses. According to the new GRBMP, water rights might well be reduced and equalized to guarantee, in addition, a more equitable distribution of irrigation water among ICs. The ICs that take water directly from the river could receive up to $6500 \mathrm{~m}^{3} / \mathrm{ha}$, whereas the remaining ones could obtain up to $7500 \mathrm{~m}^{3} /$ ha.

Each scenario was simulated under the CAP Health Check and under historical normal and dry weather conditions. According to the new CAP, direct farm payments are gradually decoupled from production and incorporated into the Single Payment Scheme, compulsory set-aside requirements are abolished in 2010, and the modulation rate increases from 5 percent in 2007 to 10 percent by 2012 (EC, 2009). Input costs for agricultural production were supposed to increase up to $5 \%$ by 2015 based on the evolution of variable costs and input prices observed in the region of study over the last decade (MARM, 2010). Crop prices (mainly for cereals and oilseeds) were incremented up to $7 \%$ in 2015 according to the estimations of the OECD-FAO (2009) and Nowicki et al. (2009). Future hydrological simulations were performed considering two types of climate sequences (normal and dry) that are derived using historical monthly precipitation and temperature records (Mitchell and Jones, 2005; AEMET, 2004). The normal climate sequence corresponds to the ten-year period that registered the median total precipitation over the past century (1901-2001). The dry climate sequence is associated to the historical ten-year period that registered $20 \%$ less of total precipitation and a $1{ }^{\circ} \mathrm{C}$ temperature increase with respect to the previously defined normal situation. Fig. 4 depicts the climate sequences selected and projected in time to cover the modeling period 2007-2015.

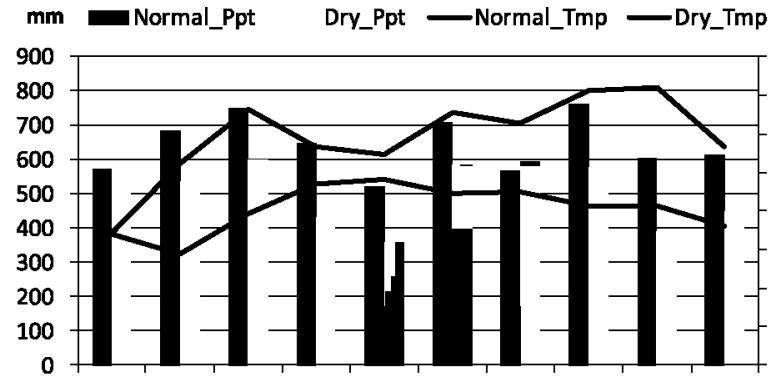

2007200820092010201120122013201420152016

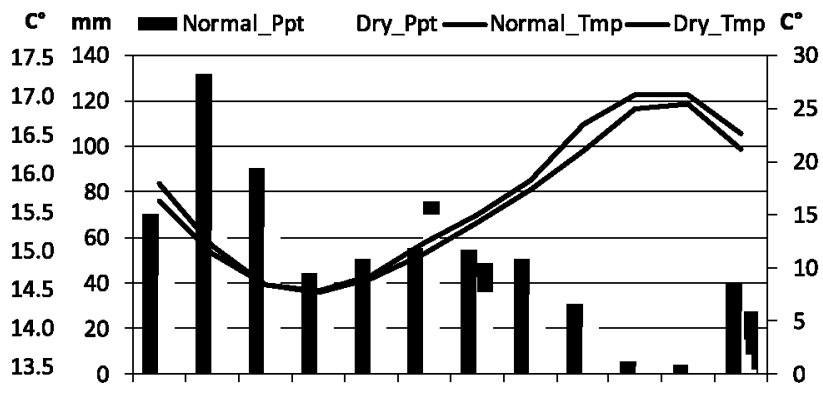

Oct Nov Dic Jan Feb Mar Apr May Jun Jul Ago Sep

Fig. 4. Normal and dry annual and monthly average weather conditions for the 2007-2016 period. 
Table 6

Impacts resulting from BAU trends under normal and dry climate conditions (2007-2015).

\begin{tabular}{|c|c|c|c|c|c|c|c|c|}
\hline \multirow[t]{2}{*}{ Region } & \multirow[t]{2}{*}{ Year } & \multirow[t]{2}{*}{ Climate sequence } & \multicolumn{6}{|l|}{ Indicators } \\
\hline & & & $\begin{array}{l}\text { Farm } \\
\text { income }(€ / \text { ha })\end{array}$ & $\begin{array}{l}\text { Public exp. } \\
(\in / \text { ha })\end{array}$ & $\begin{array}{l}\text { Labor } \\
\text { (person-day/ha) }\end{array}$ & $\begin{array}{l}\text { Irrig. water } \\
\text { use }\left(\mathrm{m}^{3} / \mathrm{ha}\right)\end{array}$ & $\begin{array}{l}\text { Irrig. water } \\
\text { productivity }\left(€ / \mathrm{m}^{3}\right)\end{array}$ & $\begin{array}{l}\text { Water } \\
\text { cost }\left(€ / \mathrm{m}^{3}\right)\end{array}$ \\
\hline \multirow[t]{3}{*}{$\mathrm{CDO}$} & 2007 & Current & 1911 & 898 & 9.7 & 9622 & 0.199 & 0.020 \\
\hline & 2015 & Normal & 1672 & 786 & 9.6 & 9622 & 0.174 & 0.020 \\
\hline & & Dry & 1483 & 786 & 9.5 & 9596 & 0.155 & 0.019 \\
\hline \multirow[t]{3}{*}{ MCM } & 2007 & Current & 2573 & 652 & 16.9 & 7480 & 0.344 & 0.026 \\
\hline & 2015 & Normal & 2475 & 585 & 13.1 & 7480 & 0.331 & 0.026 \\
\hline & & Dry & 2326 & 585 & 12.0 & 7480 & 0.311 & 0.025 \\
\hline \multirow[t]{3}{*}{ TDG } & 2007 & Current & 2113 & 645 & 16.3 & 6725 & 0.314 & 0.048 \\
\hline & 2015 & Normal & 1960 & 529 & 11.1 & 6951 & 0.282 & 0.048 \\
\hline & & Dry & 1900 & 529 & 9.5 & 7260 & 0.273 & 0.047 \\
\hline \multirow[t]{3}{*}{ ZUJ } & 2007 & Current & 2270 & 743 & 16.9 & 5961 & 0.381 & 0.046 \\
\hline & 2015 & Normal & 2151 & 599 & 14.3 & 5955 & 0.361 & 0.046 \\
\hline & & Dry & 2134 & 590 & 13.7 & 6297 & 0.339 & 0.045 \\
\hline \multirow[t]{3}{*}{ Total } & 2007 & Current & 2113 & 777 & 13.7 & 7884 & 0.268 & 0.031 \\
\hline & 2015 & Normal & 1937 & 662 & 11.4 & 7935 & 0.244 & 0.031 \\
\hline & & Dry & 1821 & 660 & 10.7 & 8001 & 0.226 & 0.030 \\
\hline
\end{tabular}

\section{Results and discussion}

\subsection{BAU scenario: following current trends}

Results on farm income, public expenditure, agricultural labor use, irrigation water use, irrigation water productivity (expressed in economic terms), and water costs for the BAU scenario are summarized in Table 6. Simulated values are presented for the first and last year of the simulation period (2007-2015).

In the baseline situation (2007), the ICs of MCM and ZUJ present the highest farm income values, with $2573 € /$ ha and $2270 € /$ ha, respectively, derived from the cultivation of highly productive and profitable crops (subsidized maize and tomato). In ZUJ, where crops are irrigated under modern pressurized irrigation systems, a relatively small amount of irrigation water per hectare is used for food production (5961 $\mathrm{m}^{3} / \mathrm{ha}$ ), which results in a high economic productivity of irrigation water of about $0.381 € / \mathrm{m}^{3}$, found by dividing farm income by irrigation water use. Irrigators that pump water directly from the Guadiana River, such as in TDG, bear extra energy costs and, therefore, pay a price per volume of water used $0.048 € \mid$ $\mathrm{m}^{3}$ ) higher than those who withdrawal water from the irrigation canals $\left(0.027 € / \mathrm{m}^{3}\right.$ on average). This motivate TDG farmers to adopt more efficient irrigation technologies and use less water for irrigation. From a socio-economic perspective, the most disadvantaged irrigation district in the region is the rice-based IC of $\mathrm{CDO}$. Although rice is well adapted to the local agro-ecological conditions of the upstream regions, it demonstrates low profitability and high water demand. In the baseline situation, the IC of CDO presents the lowest farm income (1911 $€ /$ ha) and the highest use of irrigation water (9622 $\mathrm{m}^{3} / \mathrm{ha}$ ). Consequently, it has the lowest irrigation water productivity $\left(0.199 € / \mathrm{m}^{3}\right)$.

Results indicate that the introduction of new agricultural subsidy schemes might reduce future pressures on public spending in the region, but it will likely have a detrimental effect on agricultural income going forward. The net public expenditure, calculated as the difference between the CAP payments (public spending) and the revenues collected through water fees (public collection), will be reduced from $19 \%$ (144 €/ha) in ZUJ to $10 \%$ (67 $€ /$ ha) in MCM, from 2007 to 2015, as a consequence of the CAP Health Check measures put in place. Similarly, farm income will be reduced by between $12 \%$ ( $239 € / \mathrm{ha}$ ) in the economically disadvantaged rice farming areas of CDO and $4-5 \%(98-119 € /$ ha) in the profitable regions of MCM and ZUJ by 2015 . These results are in line with those obtained by the EU that foresees an average reduction in farm income of $7 \%$ for all EU-27 farmers by 2020 (Nowicki et al., 2009).
The new CAP architecture could also have an important effect on crop production patterns (see Fig. 5) and therefore, on agricultural labor employment.

According to other recent studies (Acs et al., 2010; Oñate et al., 2007), the decoupling of the CAP subsidies (separated aid from production) might encourage a shift from irrigated to non-irrigated agriculture. Fig. 5 shows that rice acreage will be slightly reduced, whereas rain-fed farming appears faintly in 2015. Besides, tomato, highly subsidized through production-based coupled payments in the baseline situation, will be partly displaced by maize due to the loss of its comparative advantage under the new CAP scheme. Modeling results indicate that, on average, the total area under vegetable crops could decrease from $17 \%$ to less than $5 \%$ during $2007-2015 .^{6}$ As a result, farm labor employment for the whole study region might also be declined by $17 \%$ (from 13.7 to 11.4 person-day/ha, as reported in Table 6).

Overall, changes in cropping patterns will probably not have a significant impact on the total amount of water used for irrigation. Although rain-fed appears in 2015 , tomato will be largely replaced by maize, which requires more irrigation water. As seen in Table 6 , irrigation water use in 2007 and 2015 is almost equivalent. At the end of the simulated period, farmers will still continue to use high volumes of irrigation water per hectare $\left(7935 \mathrm{~m}^{3} / \mathrm{ha}\right.$ on average), situation that could be accentuated in dry periods, when crop irrigation requirements increase and changes in crop production stress are observed.

During prolonged dry episodes, low precipitation and high evapotranspiration rates bring about an increase of irrigation water needs. Modeling results indicate that the impact of climate varies in time and space depending mainly on the distribution of the precipitation and temperature patterns during the vegetation period. Fig. 6 shows the irrigation requirements of the different crops grown in the diversified IC of MCM under dry climate conditions compared to an average climate situation.

As seen in Fig. 6, crop irrigation requirements increase considerably in years preceded by periods of little precipitation (2009-2011, 2013 and 2016). Average monthly values reveal that irrigation water is particularly necessary at the beginning and end of the crop growing season, that is in May-June and September. As also reported in other

\footnotetext{
${ }^{6}$ Most of the tomatoes produced in the region are processed and sold to the local industry, which will likely increase the prices paid for processing tomatoes to keep the traditional production levels. This situation could mitigate the reduction in tomato acreage predicted by the model.
} 


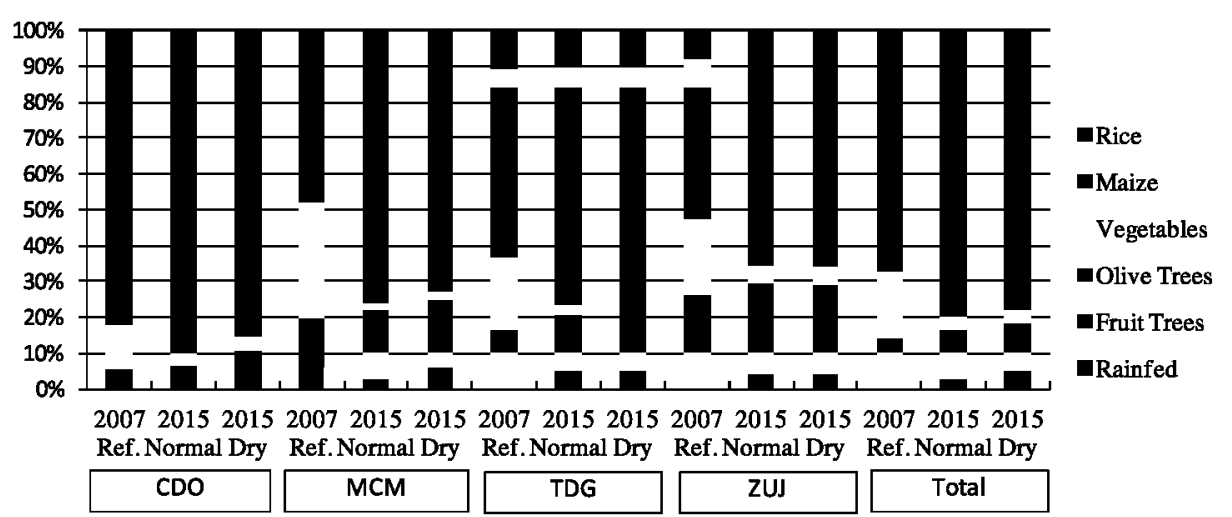

Fig. 5. Crop area distribution following BAU trends under normal and dry climate conditions (2007-2015).
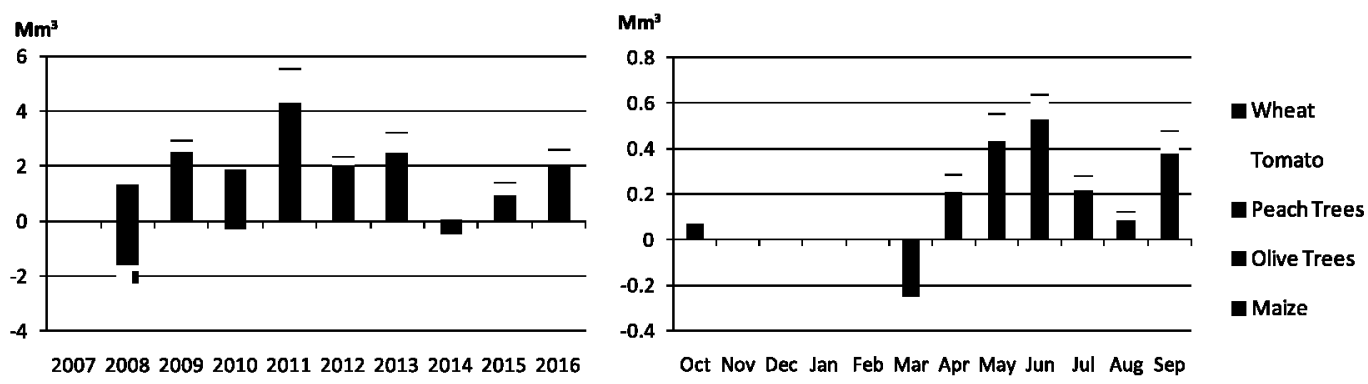

Fig. 6. Annual total and monthly average crop irrigation requirements in a dry climate cycle relative to normal in the midstream IC of MCM.

studies (Döll, 2002; Fischer et al., 2007; Maneta et al., 2009), water demand for irrigation will rise in a warmer climate depending on the type of crop and geographical location. Overall, our results point out that, under dry conditions, irrigation requirements increase moderately for cereals and vegetables (between $4 \%$ and $10 \%$ with respect to an average normal year) and substantially for perennial crops (between $13 \%$ and $25 \%$ ). Olives and fruit trees seem to be the most affected crops due to the little irrigation requirements shown by these crops during normal years and also because they need to be irrigated in spring and early fall, periods with the highest demand increases and very erratic in precipitation terms. On average, irrigation needs will be slightly higher (about 10\%) in the midstream and downstream regions of the Middle Guadiana river (the driest areas of the basin) than in upstream areas.

Results also suggest that, in times of extended drought, the provision of irrigation water could be occasionally constraint due to the limited capacity of the existing irrigation supply infrastructure. Fig. 7 shows the water level fluctuations of the two major reservoirs and irrigation channels located upstream on the Guadiana River (Zújar-Serena and Orellana) ${ }^{7}$ under a normal and dry climate cycle.

As depicted in Fig. 7, water storage in reservoirs increase during the winter-spring period, whereas it declines in the summer months in order to satisfy all water uses during this season. On the other hand, water flow in irrigation channels decreases in winter and summer, coinciding with the periods of lowest and highest irrigation water demand. In a dry climate cycle, reservoir levels drop sharply, especially in the Orellana reservoir from 2008 to 2011

\footnotetext{
${ }^{7}$ The Zujar-Serena reservoir and the Orellana reservoir (with a storage capacity of $3533 \mathrm{Mm}^{3}$ and $808 \mathrm{Mm}^{3}$, respectively) hold $55 \%$ of the total storage capacity in the Middle Guadiana basin and irrigate $60 \%(75,000 \mathrm{ha})$ of the total irrigated area in the basin.
}

and 2015/2016. During these years, water flow in the Orellana channel can become zero, which may provoke delivery shortages to the irrigation districts that take water directly from this irrigation channel, notably $\mathrm{CDO}$.

Thus, even though water courses are highly regulated in the Middle Guadiana basin, prolonged drought might increase the gap between irrigation water supply and demand and produce negative impacts on surface irrigation systems. Our findings indicate that farmers that belong to the IC of CDO and MCM might lose up to $22 \%$ ( $428 € /$ ha) and $10 \%$ (247 $€ /$ ha) of their income by 2015 in comparison to the baseline situation in 2007, when dealing with dry conditions (see Table 6). In the Zujar-Serena reservoir, water fluctuations are less pronounced, which evidence the high capacity of the big reservoirs to mitigate potential drought impacts. In ZUJ, IC that take water from the Zújar irrigation canal, supplemental irrigation is provided to deal with dry-spells. As a consequence, farm income in ZUJ will be reduced by about $6 \%(136 € /$ ha) by the end of the simulated dry period, only $1 \%$ more than in an average climate situation (see Table 6).

\subsection{EU policy-driven scenario: implementing minimum environmental flows}

The average monthly percent coverage of environmental flow requirements for the studied normal and dry climate periods (2007-2015) is shown in Fig. 8.

The simulation results indicate that the minimum environmental flows specified in Table 5 are not completely covered in some river reaches (Lacara, Matachel II and Guadiana V). Fig. 8 illustrates that, in a normal climate cycle, Lacara and Matachel II lack water from October to April-June, whereas in Guadiana V, low summer flows are insufficient to maintain the basic ecological functioning from July to October. In a dry climate cycle, the number 
(a)

Orellana

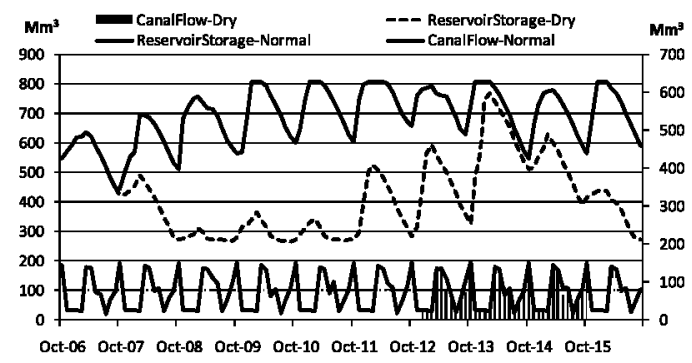

(b)

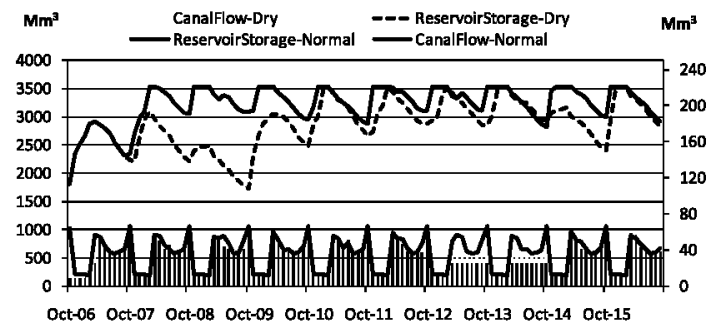

Fig. 7. Water level fluctuations in major reservoirs and irrigation channels under normal and dry climate conditions.

of months with unmet flow requirements increases and monthly coverage rates decrease, reaching a minimum of $47 \%$ in February at Lacara, 79\% also in February at Matachell II, and 57\% in August at Guadiana V. Additionally, about $92 \%$ of flow requirements are met in October at Zujar II under dry weather conditions.

Our findings also reveal that complying with the environmental flows could entail water supply reductions on other domestic and agricultural water uses, especially during dry periods (see Fig. 9).

Fixed amounts of water allocated for environmental flows will change the flow patterns of rivers and hence, the availability of water. Fig. 9 shows that the group of cities of Lacara, with approximately 30,000 inhabitants, would receive $38 \%$ ( $1 \mathrm{Mm}^{3} /$ year) and $45 \%$ (1.2 $\mathrm{Mm}^{3} /$ year) less water under normal and dry climate conditions, respectively, if environmental flows are implemented. Similarly, the amount of water supplied to the upstream irrigation district of CDO to satisfy crop water needs might decrease by $17 \%$ (70 $\mathrm{Mm}^{3} /$ year) and $40 \%$ (177 $\mathrm{Mm}^{3} /$ year) under normal and dry climate conditions, respectively, when minimum instream flows are imposed. Under all climate scenarios, the months of July and August are periods with significant unmet environmental demands and high irrigation water requirements, evidencing a clear clash between environmental and agricultural water uses during summer low-flow periods.
Results suggest that the establishment of minimum environmental flows as a mechanism to achieve a GES in rivers could trim down the amount of water made available for irrigation and consequently, adversely affect farmers' income in the region. Thus, any policy addressed to achieve the WFD's environmental objectives in the basin should not only consider specific bio-geophysical conditions within river systems, but also socio-institutional, technical and structural factors across irrigation districts. The importance of studying affected human actors has been also highlighted by Acreman and Ferguson (2010), where the authors analyze the natural-human implications of establishing environmental flows in the UK.

Table 7 shows the results of the application of environmental flows regimes across ICs on farm income, land use, irrigation water use, irrigation water productivity, water costs, and water shadow prices, which correspond to the marginal value of relaxing the water availability constraint (Eq. (7) of the economic model).

As seen in Table 7, the application of environmental flows in the Middle Guadiana basin would result in a $9 \%\left(678 \mathrm{~m}^{3} / \mathrm{ha}\right)$ reduction in irrigation water use and a $3 \%(50 € /$ ha $)$ loss of farm income. These figures could go up to $19 \%\left(1488 \mathrm{~m}^{3} / \mathrm{ha}\right)$ and $9 \%(179 € / \mathrm{ha})$, when facing dry conditions. In particular, CDO will experience a decrease of $17 \%\left(1648 \mathrm{~m}^{3} / \mathrm{ha}\right)$ and $40 \%\left(3877 \mathrm{~m}^{3} / \mathrm{ha}\right)$ in the amount of water per hectare delivered to farmers and a reduction of $7 \%$ (117 €/ha) and 20\% (336€/ha) in farmers' income under normal and dry climate conditions, respectively, which may put at risk the economic viability of rice farming households in the area.

This situation incentivizes farmers to change their crop choice, who will partially substitute irrigated land (mainly rice) with rainfed crops (see Table 7). In contrast, water shortages will not significantly reduce the area cultivated under perennial crops (high-value, low water-intensive fruit plantations and olive trees), which will increase its relative importance in the share of the total irrigated area under more restrictive water situations. As a result, irrigation water use will be more heavily reduced than farm income and irrigation water productivity in the basin will increase from $0.244 € / \mathrm{m}^{3}$ to $0.254 € / \mathrm{m}^{3}$ and $0.263 € / \mathrm{m}^{3}$ under normal and dry conditions, respectively. These findings indicate that the implementation of the EU WFD might contribute not only to restore the aquatic ecosystems, but also to make irrigation water more economically productive.

Water shadow prices, in Table 7, reflect the marginal opportunity cost of imposing environmental constraints on irrigation water use and thus, can be used as reference values for designing efficient pricing policies (González-Âlvarez et al., 2006; Pulido-Velázquez et al., 2008; Ward and Michelsen, 2002). Our results indicate that water shadow prices rise over the whole basin and notably, in CDO,

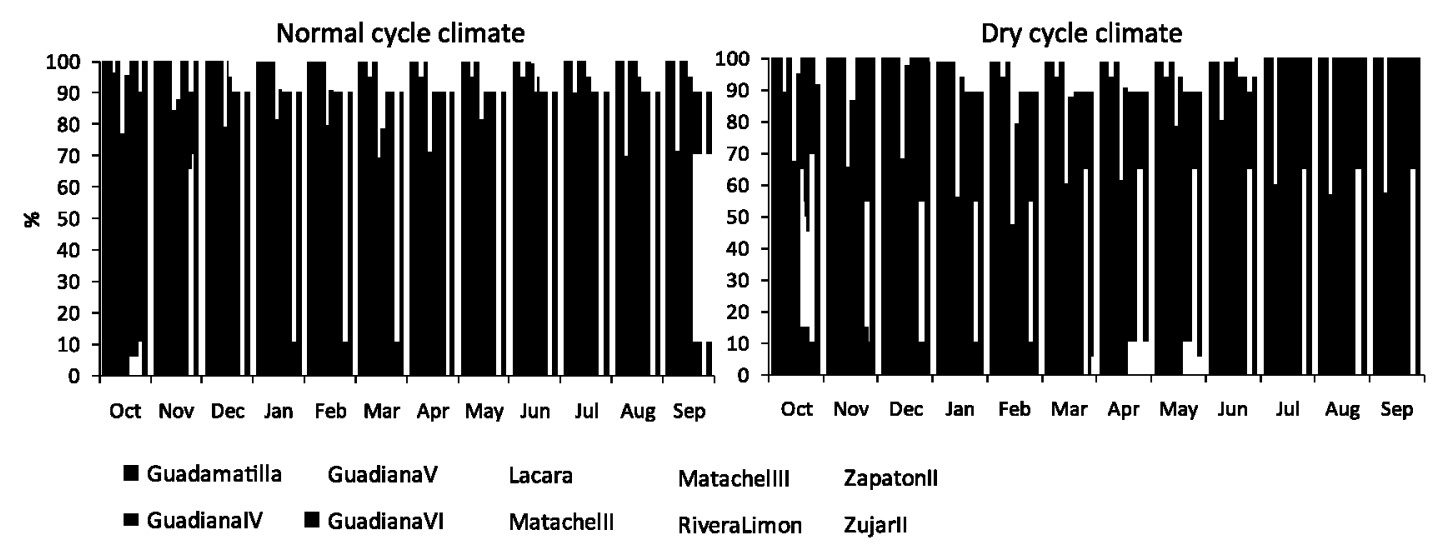

Fig. 8. Monthly average flow requirement coverage (\% of requirement met) under normal and dry climate cycle. 


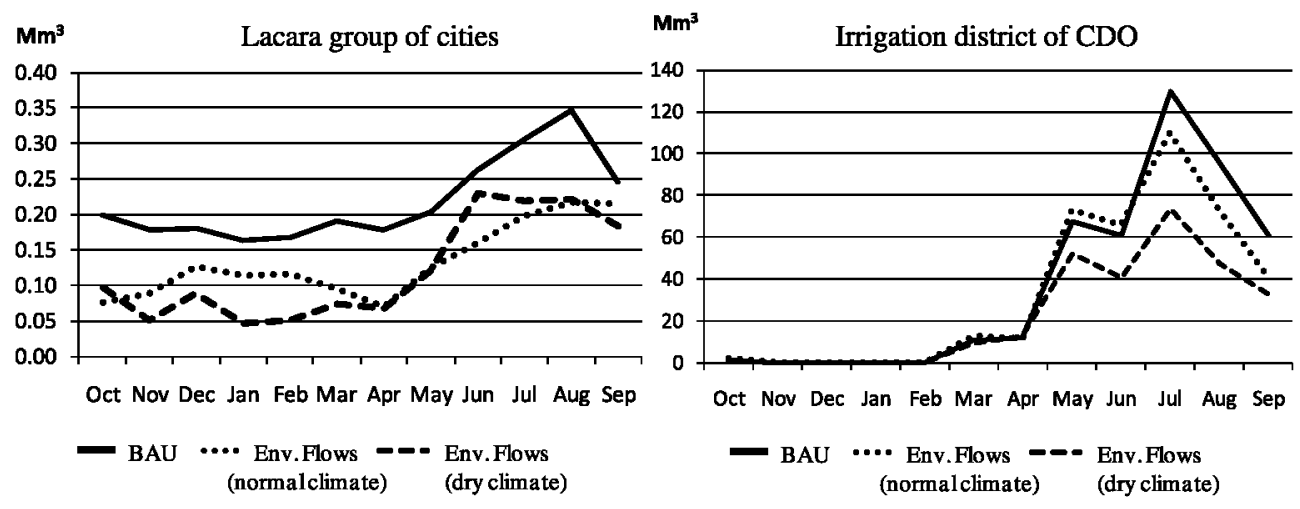

Fig. 9. Average water supply deliveries to different domestic and agricultural uses under normal and dry climate conditions when complying with the environmental flows.

Table 7

Effects of the application of environmental flows under normal and dry climate conditions in 2015.

\begin{tabular}{|c|c|c|c|c|c|c|c|c|}
\hline \multirow[t]{2}{*}{ Region } & \multirow{2}{*}{$\begin{array}{l}\text { Water } \\
\text { policy }\end{array}$} & \multirow{2}{*}{$\begin{array}{l}\text { Climate } \\
\text { sequence }\end{array}$} & \multicolumn{6}{|c|}{ Indicators } \\
\hline & & & $\begin{array}{l}\text { Income } \\
(€ / h a)\end{array}$ & $\begin{array}{l}\text { Irrg. water } \\
\text { use }\left(\mathrm{m}^{3} / \mathrm{ha}\right)\end{array}$ & $\begin{array}{l}\text { Irrig. water } \\
\text { productivity }\left(€ / \mathrm{m}^{3}\right)\end{array}$ & $\begin{array}{l}\text { Water cost } \\
\left(€ / \mathrm{m}^{3}\right)\end{array}$ & $\begin{array}{l}\text { Water shadow } \\
\text { prices }\left(€ / \mathrm{m}^{3}\right)\end{array}$ & Irrigated/Rainfed (\%) \\
\hline \multirow[t]{3}{*}{$\mathrm{CDO}$} & BAU & Normal & 1672 & 9622 & 0.174 & 0.020 & 0.026 & $99 / 1$ \\
\hline & WFD & Normal & 1555 & 8045 & 0.193 & 0.021 & 0.039 & $72 / 28$ \\
\hline & & Dry & 1336 & 5816 & 0.230 & 0.025 & 0.041 & $55 / 45$ \\
\hline \multirow[t]{3}{*}{ MCM } & BAU & Normal & 2475 & 7480 & 0.331 & 0.026 & 0.031 & $95 / 5$ \\
\hline & WFD & Normal & 2475 & 7480 & 0.331 & 0.026 & 0.031 & $95 / 5$ \\
\hline & & Dry & 2326 & 7480 & 0.311 & 0.026 & 0.029 & $82 / 18$ \\
\hline \multirow[t]{3}{*}{ TDG } & BAU & Normal & 1960 & 6951 & 0.282 & 0.048 & 0.019 & $95 / 5$ \\
\hline & WFD & Normal & 1960 & 6951 & 0.282 & 0.048 & 0.019 & $95 / 5$ \\
\hline & & Dry & 1900 & 7260 & 0.262 & 0.047 & 0.016 & $90 / 10$ \\
\hline \multirow[t]{3}{*}{ ZUJ } & BAU & Normal & 2151 & 5955 & 0.361 & 0.046 & - & $96 / 4$ \\
\hline & WFD & Normal & 2151 & 5955 & 0.361 & 0.046 & - & $96 / 4$ \\
\hline & & Dry & 2134 & 6297 & 0.339 & 0.045 & 0.015 & $94 / 6$ \\
\hline \multirow[t]{3}{*}{ Total } & BAU & Normal & 1937 & 7935 & 0.244 & 0.031 & 0.025 & $97 / 3$ \\
\hline & WFD & Normal & 1887 & 7257 & 0.254 & 0.031 & 0.034 & $85 / 15$ \\
\hline & & Dry & 1758 & 6447 & 0.263 & 0.032 & 0.030 & $75 / 25$ \\
\hline
\end{tabular}

when environmental flows are implemented. In CDO, the marginal value of irrigation water increase from $0.026 € / \mathrm{m}^{3}$ in the baseline situation to $0.039 € / \mathrm{m}^{3}$ and $0.041 € / \mathrm{m}^{3}$ under normal and dry climate conditions, respectively. As seen in Table 7 , the marginal opportunity cost of irrigation water is almost two times higher that the unit cost of water, currently fixed at $0.02 € / \mathrm{m}^{3}$. Similar results have been obtained by Blanco-Gutiérrez et al. (2011) and Garrido and Calatrava (2010), which demonstrate that current water prices in Spain, basically designed to cover the financial cost of irrigation water services, should be doubled for fully recovering the environmental and resource costs, as required by the EU WFD (Art, 9).

\subsection{National policy-driven scenario: reducing water supply for irrigation}

Results of the reduction in the legal amount of water delivered for irrigation (contemplated in the new GRBMP) on farm income, land use, irrigation water use, irrigation water productivity, water costs, and water shadow prices are depicted in Table 8.

As seen in Table 8, irrigation water use is reduced by $34 \%$ $\left(3247 \mathrm{~m}^{3} / \mathrm{ha}\right)$ and $12 \%\left(880 \mathrm{~m}^{3} / \mathrm{ha}\right)$ in CDO and MCM respectively, and by $11 \%$ ( $\left.776 \mathrm{~m}^{3} / \mathrm{ha}\right)$ in TDG when more restrictive water concessions are implemented. ${ }^{8} \mathrm{~A}$ different behavior can be observed in the very modern IC of $\mathrm{ZUJ}$, where the levels of water used for

\footnotetext{
${ }^{8}$ Water availability in the IC of TDG is only binding for the representative farm $F_{8}$ situated upstream on the Guadiana River, which cultivates a large surface of rice.
}

irrigation are already below the new established water rights and therefore, farmers are not affected by the implementation of tighter water supply regimes. The highly efficient use of water in ZUJ during normal years allows this irrigation district to apply larger quantities of water during dry periods to mitigate the impact of drought.

Overall, the new system of water concessions could reduce by $21 \%$ the total amount of irrigation water used in the basin $\left(1675 \mathrm{~m}^{3}\right.$ ) ha, that is, $227.8 \mathrm{Mm}^{3}$ ). Results indicate that in spite of decreasing irrigation water use, the minimum environmental flows set in Lacara and Matachel Il would remain uncovered in almost all months from October to April. Even so, lower rates of irrigation withdrawals might contribute to rise water levels in the Guadiana river and facilitate compliance with minimum flows in the exploited Guadiana V river reach. Coverage rates in Guadiana V could increase from $70 \%$ (in the baseline situation) to $82 \%$ and $90 \%$ in the new GRBMP scenario under dry and normal climate conditions, respectively.

As expected, farmers adapt to changes in weather patterns and water availability by adjusting their crops and irrigation technologies to minimize adverse impacts (see Fig. 10).

Fig. 10 suggests that the implementation of more restrictive water concessions will imply a substantial increase of rain-fed areas, particularly in MCM and CDO (between 16\% and 34\%). Rain-fed wheat fields could gain ground in detriment of waterintensive cereals, like maize and notably rice, which may even disappear from some regions (TDG) in periods of extended drought. The cultivation of vegetables and perennial crops (fruit and olive trees), commonly irrigated in the study area under pressurized 
Table 8

Effects of the application of more restrictive water allotments for agriculture under normal and dry climate conditions in 2015.

\begin{tabular}{|c|c|c|c|c|c|c|c|c|}
\hline \multirow[t]{2}{*}{ Region } & \multirow{2}{*}{$\begin{array}{l}\text { Water } \\
\text { policy }\end{array}$} & \multirow{2}{*}{$\begin{array}{l}\text { Climate } \\
\text { sequence }\end{array}$} & \multicolumn{6}{|c|}{ Indicators } \\
\hline & & & $\begin{array}{l}\text { Income } \\
(€ / \text { ha) }\end{array}$ & $\begin{array}{l}\text { Irrig. water } \\
\text { use }\left(\mathrm{m}^{3} / \mathrm{ha}\right)\end{array}$ & $\begin{array}{l}\text { Irrig. water } \\
\text { productivity }\left(€ / \mathrm{m}^{3}\right)\end{array}$ & $\begin{array}{l}\text { Water cost } \\
\left(€ / \mathrm{m}^{3}\right)\end{array}$ & $\begin{array}{l}\text { Water shadow } \\
\text { prices }\left(€ / \mathrm{m}^{3}\right)\end{array}$ & Irrigated/Rainfed (\%) \\
\hline \multirow[t]{3}{*}{ CDO } & BAU & Normal & 1672 & 9622 & 0.174 & 0.020 & 0.026 & $99 / 1$ \\
\hline & GRBMP & Normal & 1505 & 6375 & 0.236 & 0.024 & 0.041 & $65 / 35$ \\
\hline & & Dry & 1420 & 6375 & 0.223 & 0.024 & 0.038 & $60 / 40$ \\
\hline \multirow[t]{3}{*}{ MCM } & BAU & Normal & 2475 & 7480 & 0.331 & 0.026 & 0.031 & $95 / 5$ \\
\hline & GRBMP & Normal & 2350 & 6600 & 0.356 & 0.028 & 0.034 & $79 / 21$ \\
\hline & & Dry & 2256 & 6600 & 0.342 & 0.028 & 0.032 & $73 / 27$ \\
\hline \multirow[t]{3}{*}{ TDG } & BAU & Normal & 1960 & 6951 & 0.282 & 0.048 & 0.019 & $95 / 5$ \\
\hline & GRBMP & Normal & 1901 & 6175 & 0.308 & 0.049 & 0.022 & $85 / 15$ \\
\hline & & Dry & 1862 & 6175 & 0.302 & 0.049 & 0.020 & $80 / 20$ \\
\hline \multirow[t]{3}{*}{ ZUJ } & BAU & Normal & 2151 & 5955 & 0.361 & 0.046 & - & $96 / 4$ \\
\hline & GRBMP & Normal & 2151 & 5955 & 0.361 & 0.046 & - & $96 / 4$ \\
\hline & & Dry & 2136 & 6504 & 0.328 & 0.045 & - & $96 / 4$ \\
\hline \multirow[t]{3}{*}{ Total } & BAU & Normal & 1937 & 7935 & 0.244 & 0.031 & 0.025 & $97 / 3$ \\
\hline & GRBMP & Normal & 1838 & 6260 & 0.284 & 0.033 & 0.035 & $78 / 22$ \\
\hline & & Dry & 1778 & 6383 & 0.269 & 0.033 & 0.033 & $74 / 26$ \\
\hline
\end{tabular}

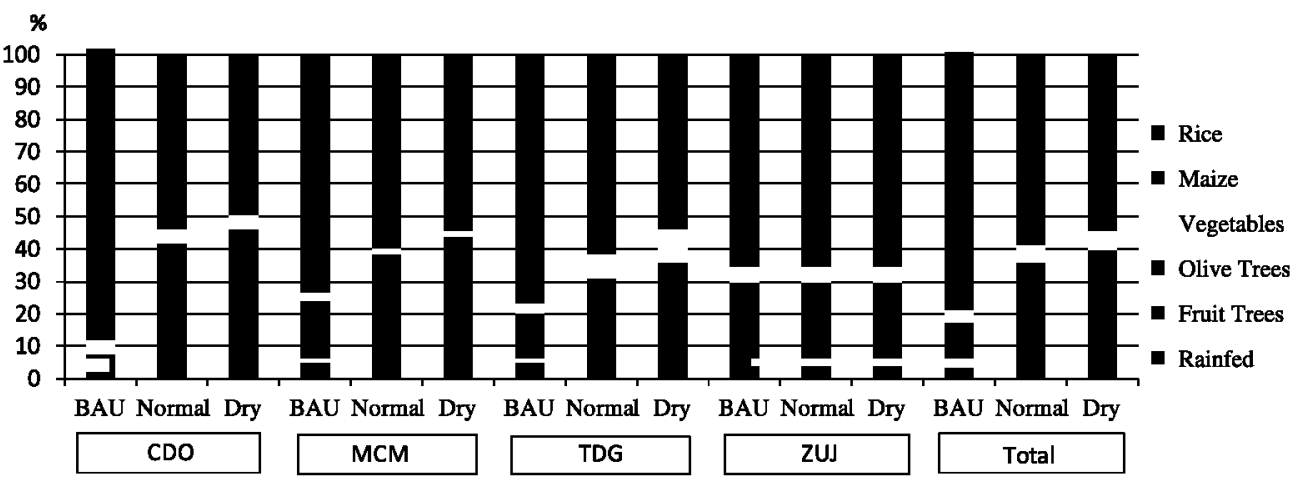

Fig. 10. Cropping patterns adopted by farmers when more restrictive water allotments are implemented under normal and dry climate conditions.

irrigation systems, will be reinforced as much as possible in ICs equipped with modern irrigation technologies, such as TDG.

As reported in previous studies (see e.g. Iglesias et al., 2003; Reidsma and Ewert, 2008; Smit and Skinner, 2002), our results reveal that the structural and technical characteristics of the irrigation districts, such as farm size, cropping mix potential, type of irrigation systems, and farming operations, clearly determine farmer's capacity to adapt to different climate and political stimuli. It can be observed that $\mathrm{CDO}$ and MCM, characterized by large water concessions, the use of conventional gravity-irrigation systems and by predominance, notably in CDO, of small and non-diversified farms, will be the most negatively affected in economic terms by a reduction in irrigation water supply, and the most vulnerable when facing dry weather conditions. As seen in Table 8, CDO farmers could lose up to $10 \%$ ( $167 € /$ ha) of their income if tighter water concessions were finally implemented. Expected income losses are reduced to $5 \%$ ( $125 € /$ ha) in MCM and $3 \%$ (58€/ha) in TDG. In dry periods, the adverse effects of irrigation supply cuts will be enhanced. Farm income could be additionally reduced by between $1 \%$ (15€/ha) in $\mathrm{ZUJ}$ and $6 \%$ ( $85 € /$ ha) in CDO.

As seen above, the new water use concession scheme relatively benefit, in economic terms, the cultivation of profitable low water intensive crops as those grown under pressurized irrigation systems in ZUJ and TDG. Therefore, a more restrictive, but more equitable distribution of irrigation water among ICs might substantially reduce irrigation water use and encourage irrigation modernization, promoting water efficiency and productivity in the basin. Table 8 shows that the economic productivity of irrigation water will increase with the new water use concession system in all ICs, reaching an average value of $0.284 € / \mathrm{m}^{3}$ (higher than the one obtained under the WFD scenario). Although irrigation return flows are considered in the study, future research would be needed to investigate the role that the adoption of more efficient irrigation technologies can play in achieving 'real' water savings at the basin scale, as examined by Molden et al. (2010), Ward and PulidoVelázquez (2008).

\section{Conclusions and reflections}

This paper describes the development and application of a policy-relevant economic-hydrologic model, whose ability lies in reflecting complex interrelationships between farmers' economic behavior and hydrological processes within a flexible but robust integrated framework, in which all relevant components of water demand and supply, from the field to the basin level, are taken into account. A number of limitations need to be considered. First, some difficulties may arise from the exclusion of financial constraints from the model. Farmers are presumed to be financially solvent and to dispose of sufficient financial reserves and net current assets to acquire new production techniques and inputs. Second, all crops share the same water use priority. Irrigation water is distributed proportionally among crops, whereas in some cases (e.g. under conditions of severe water shortage) water transfers from annual to perennial crops might be desirable to protect capital investments. Third, yield response to irrigation water is represented by a discontinue crop production function. An interesting topic to discuss 
in further research is the inclusion of a non-linear agronomic model, which could better represent crop-water-yield relationships and allow the existence of an interior solution to the optimization problem even if the risk aversion coefficient is zero. However, despite of these limitations, this integrated economic-hydrologic model has proven to be a robust tool to analyze the socioeconomic and environmental consequences of policy changes and climate variations in semi-arid irrigation-dominated basins, as it is the case of the Middle Guadiana basin in Southwest Spain.

Considering a business-as-usual scenario, the analysis suggests that agricultural income and employment in the Middle Guadiana basin could be substantially reduced by 2015 (deadline established by the EU WFD for achieving environmental goals), as a consequence of the implementation of the EU CAP Health Check reform. The decoupling of farm subsidies established by the new CAP might produce a shift in crop production toward a more cereal-dominated landscape with little effect on the total amount of water used for irrigation. Therefore, unless corrective water measures are taken, it seems likely that farmers will continue to use high volumes of irrigation water per hectare in 2015, which might jeopardize the goal of achieving 'good environmental status' in the Middle Guadiana basin. Along these lines, the results obtained indicate that minimum environmental flows might not be secured in some river reaches (Lacara, Matachel II, and Guadiana V), endangering the sustainability of vital aquatic species and habitats. The clash between environmental and agricultural water uses could even be stressed during prolonged dry episodes and notable, in summer months, when water demand for irrigation increases. Higher temperatures accompanied by lower amounts of rainfall and higher rates of evapotranspiration will increase irrigation water requirements slightly for cereals and vegetables and substantially for perennial crops, especially in the driest areas of the basin (midstream and downstream regions).

Securing minimum environmental flows to fulfill the WFD requirements in the basin could entail a substantial reduction of water supplied to other domestic and agricultural uses, giving rise to unmet demands and opportunity costs. Particularly, upstream on the Middle Guadiana river, complying with environmental flows to maintain the basic ecological functioning of the Guadiana $V$ river reach in dry periods might diminish up to $40 \%$ the amount of irrigation water made available to rice-growing farmers in CDO, who could see their income reduced by $20 \%$, seriously affecting the productivity and economic viability of rice farming in this area.

A possible reduction in irrigation water supply in the terms established by the new GRBMP could decline total irrigation withdrawals by $21 \%$ and therefore, contribute to maintain higher base flows in rivers, but it may not be sufficient to fully restore environmental flows in the 'risked' river reaches of the Middle Guadiana basin, as required by the WFD. A thoroughly revision of the water use concession system applied in the basin seems to be needed in order to bring the GRBMP in line with WFD objectives. As expected, tighter irrigation supply regimes could entail significant farm income losses, notably in ICs with high water concessions, smallholder farms, low crop diversification and low water use (technical) efficiency, regardless of their geographical location. In view of that, CDO and MCM seem to be the ICs most negatively affected in economic terms by a reduction in irrigation water deliveries, and the most vulnerable when facing dry climate conditions. In addition, results show that the new planned limit of irrigation water use might encourage the cultivation of waterefficient high-value crops (such as vegetables and fruit trees) and therefore, contribute to increase economic water productivity in the irrigation systems of the Middle Guadiana basin.
The study illustrates that social, economic, institutional, and technological factors, in addition to bio-physical conditions, are important issues to be considered for designing and developing water management strategies. The research initiative presented in this paper demonstrates that hydro-economic models can explicitly integrate all these issues, constituting a valuable tool that could assist policy makers for implementing sustainable irrigation policies.

\section{Acknowledgments}

This research was carried out under the joint funding of the EU projects SCENES (Water Scenarios for Europe and for Neighboring States, from the EC FP6, $n^{\circ}$ 036822) and MEDIATION (Methodology for Effective Decision-making on Impacts and AdaptaTION, from the EC FP7, n 244012). FPU scholarship (AP2007-00433) from the Spanish Ministry of Sciences and Education and a GEIGRAM grant to I.B. are also acknowledged. We wish to express our gratitude to the research teams of the SEI-US center and especially to Marisa Escobar for her valuable insights throughout the research developments and her technical support provided in the application of the WEAP model.

\section{References}

Acreman, M.C., Ferguson, A.J.D., 2010. Environmental flows and the European water framework Directive. Freshwater Biology 55, 32-48.

Acs, S., Hanley, N., Dallimer, M., Gaston, K.J., Robertson, P., Wilson, P., Armsworth, P.R., 2010. The effect of decoupling on marginal agricultural systems: implications for farm incomes, land use and upland ecology. Land Use Policy 27, 550-563.

AEMET (Agencia Española de Meteorología) 2004 Guía resumida del clima en España 1971-2000. In: Plan Estadístico Nacional 2001-2004. Spanish Ministry of Environment and Rural and Marine Affairs.

Ahrends, H., Mast, M., Rodgers, C., Kunstmann, H., 2008. Coupled hydrologicaleconomic modelling for optimised irrigated cultivation in a semi-arid catchment of West Africa. Environmental Modelling \& Software 23, 385-395.

Allen, R.G., Pereira, L.S., Raes, D., Smith, M., 1998. Crop evapotranspiration. guidelines for computing crop water requirements. In: Irrigation and Drainage Paper Italy, No. 56. FAO, Rome, 300 pp.

Becker, N., Friedler, E., 2013. Integrated hydro-economic assessment of restoration of the Alexander-Zeimar River (Israel-Palestinian Authority). Regional Environmental Change 13, 103-114.

Binswanger, H.P., 1980. Attitudes toward risk: experimental measurement in rural India. American Journal of Agricultural Economics 62 (3), 395-407.

Blanco-Gutiêrrez, I., Varela-Ortega, C., Flichman, G., 2011. Cost-effectiveness of water conservation measures: a multi-level analysis with policy implications. Agricultural Water Management 98, 639-652.

Booker, J.F., Howitt, R.E., Michelsen, A.M., Young, R.A., 2012. Economics and the modeling of water resources and policies. Natural Resource Modeling Journal 25 (1), 168-218.

Brouwer, R., Hofkes, M., 2008. Integrated hydro-economic modelling: approaches, key issues and future research directions. Ecological Economics 66, 16-22.

CCU-SEI (Centro de Cambio Global-Universidad Católica de Chile, Stockholm Environment Institute), April 2009. Guía metodológica - Modelación hidrológica y de recursos hídricos con el modelo WEAP. Santiago (Chile) and Boston (USA). Available online at: www.weap21.org.

Chavas, J.P., 2004. Risk Analysis in Theory and Practice. Elsevier Academic Press.

CHG (Confederación Hidrográfica del Guadiana), 2008. Estudio general de la Demarcación Hidrográfica del Guadiana. Parte I. Spanish Ministry of the Environment and Rural and Marine Affairs, Badajoz, Spain.

CHG (Confederación Hidrográfica del Guadiana), 2009. Requerimientos de caudales ecológicos en la Demarcación Hidrográfica del Guadiana. In: Elaboración del Plan Hidrológico 2009. Spanish Ministry of the Environment and Rural and Marine Affairs, Badajoz, Spain.

Croke, B.F.W., Ticehurst, J.L., Letcher, R.A., Norton, J.P., Newham, L.T.H., Jakeman, A.J., 2007. Integrated assessment of water resources: Australian experiences. Water Resources Management 21, 351-373.

Döll, P., 2002. Impact of climate change and variability on irrigation requirements: a global perspective. Climate Change 54, 269-293.

EC (European Commission), 2000. Directive 2000/60/EC of the European Parliament and of the Council of 23 October 2000 Establishing a Framework for Community Action in the Field of Water Policy. OJEC L327. Office for Official Publications of the European Communities, Luxembourg.

EC (European Commission), 2009. Council Regulation (EC) No 73/2009 of 19 January 2009 Establishing Common Rules for Direct Support Schemes for Farmers under the Common Agricultural Policy and Establishing Certain Support Schemes 
for Farmers. OJEC L 30. Office for Official Publications of the European Communities, Luxembourg.

Fischer, G., Tubiello, F.N., Van Velthuizen, H., Wiberg, D.A., 2007. Climate change impacts on irrigation water requirements: effects of mitigation, 1990-2080. Technological Forecasting and Social Change 74, 1083-1107.

Friedman, M., Savage, L.J., 1948. The utility analysis of choices involving risk. The Journal of Political Economy 56, 279-304.

Garrido, A., Calatrava, J., 2010. Recent and future trends in water charging and water markets. In: Garrido, A., Llamas, M.R. (Eds.), Water Policy in Spain. Taylor \& Francis Group, London, UK.

George, B., Malano, H., Davidson, B., Hellegers, P., Bharati, L., Massuel, S., 2011. An integrated hydro-economic modelling framework to evaluate water allocation strategies II: scenario assessment. Agricultural Water Management 98 $747-758$.

Gleick, H.P., Cooley, H., Cohen, M., Morikawa, M., Morrison, J., Palaniappan, M., 2009. The world's water 2008-2009: the biennial report on freshwater resources. Island Pr, Washington, D.C.

Gohar, A.A., Ward, F.A., 2010. Gains from expanded irrigation water trading in Egypt: an integrated basin approach. Ecological Economics 69, 2535-2548.

Gómez-Limón, J.A., Riesgo, L., 2004. Irrigation water pricing: differential impacts on irrigated farms. Agricultural Economics 31, 47-66.

Gómez-Limón, J.A., Riesgo, L., 2009. Alternative approaches to the construction of a composite indicator of agricultural sustainability: an application to irrigated agriculture in the Duero basin in Spain. Journal of Environmental Management $90,3345-3362$.

González del Tánago, M., García de Jalón, D., Romản, M., 2012. River restoration in Spain: theoretical and practical approach in the context of the European Water Framework Directive. Environmental Management 50 (1), 123-139.

González-Âlvarez, Y., Keeler, A.G., Mullen, J.D., 2006. Farm-level irrigation and the marginal cost of water use: evidence from Georgia. Journal of Environmental Management 80 (4), 311-317.

Hardinan, R.T., Lacey, R., Yang, M.Y., 1990. Use of cluster-analysis for identification and classification of farming systems in Qingyang county, central North China. Agricultural Systems 33 (2), 115-125.

Harou, J.J., Medellín-Azuara, J., Zhu, T., Tanaka, S.T., Lund, J.R., Stine, S., Olivares, M.A. Jenkins, M.W., 2010. Economic consequences of optimized water management for a prolonged, severe drought in California. Water Resources Research 46 , W05522.

Harou, J.J., Pulido-Velázquez, M., Rosenberg, D.E., Medellín-Azuara, J., Lund, J.R., Howitt, R.E., 2009. Hydro-economic models: concepts, design, applications, and future prospects. Journal of Hydrology $375,627-643$.

Hazell, P.B., Norton, R.D., 1986. Mathematical Programming for Economic Analysis in Agriculture. Macmillan Publishing Company, New York, USA.

Heinz, I., Pulido-Velázquez, M., Lund, J., Andreu, J., 2007. Hydro-economic modeling in river basin management: implications and applications for the European Water Framework Directive. Water Resources Management 21 $1103-1125$

Henseler, M., Wirsig, A., Herrmann, S., Krimly, T., Dabbert, S., 2009. Modeling the impact of global change on regional agricultural land use through an activity-based non-linear programming approach. Agricultural Systems 100 $31-42$.

Iglesias, E., Garrido, A., Gómez-Ramos, A., 2003. Evaluation of drought management in irrigated areas. Agricultural Economics 29, 211-229.

IGN (Instituto Geográfico Nacional), 2004. Actualización de la base de datos Corine Land Cover. Proyecto I\&CLC2000. Final report by the National Geographic Institute of Spain, Madrid, Spain.

INE (Instituto Nacional de Estadística), 1999. Censo Agrario 1999. Ministry of Economy and Tax, Madrid, Spain.

INE (Instituto Nacional de Estadística), 2007. Encuesta sobre la estructura de las explotaciones agrícolas en Extremadura. Ministry of Economy and Tax, Madrid, Spain.

JE (Junta de Extremadura), 2007. Datos estadísticos sobre el sector agropecuario y forestal de Extremadura. Regional Department of Agriculture and Rural Development. Autonomous Government of Extremadura, Badajoz, Spain.

Tha, M.K., Gupta, A.D., 2003. Application of Mike Basin for water management strategies in a watershed. Water International 28, 27-35.

Kanellopoulos, A., Berentsen, P., Heckelei, T., Van Ittersum, M., Lansink, A.O., 2010 Assessing the forecasting performance of a generic bio-economic farm mode calibrated with two different PMP variants. Journal of Agricultural Economics $61,274-294$

Kemp-Benedict, E.J., Bharwani, S., Fischer, M.D., 2010. Methods for linking social and physical analysis for sustainability planning. Ecology and Society 15 (3), 4

Köbrich, C., Rehman, T., Khan, M., 2003. Typification of farming systems for constructing representative farm models: two illustrations of the application of multi-variate analyses in Chile and Pakistan. Agricultural Systems 76 (1), $141-157$

Kragt, M.E., Newhama, L.T.H., Bennett, J., Jakeman, A.J., 2011. An integrated approach to linking economic valuation and catchment modelling. Environmental Modelling \& Software 26 (1), 92-102.

Krysanova, V., Dickens, C., Timmerman, J., Varela-Ortega, C., Schlüter, M., Roest, K. Huntjens, P., Jaspers, F., Buiteveld, H., Moreno, E., De Pedraza-Carrera, J. Slámová, R., Martinkova, M., Blanco, I., Esteve, P., Pringle, K., Pahl-Wostl, C. Kabat, P., 2010. Cross-comparison of climate change adaptation strategies across large river basins in Europe, Africa and Asia. Water Resources Management 24, $4121-4160$.
Labadie, J., 2011. MODSIM-DSS Water Rights Planning, Water Resources management \& River Operations Decision Support System. In: Documentation and User Manual. Colorado State University.

Lopez-Gunn, E., Zorrilla, P., Prieto, F., Llamas, M.R., 2012. Lost in translation? Water efficiency in Spanish agriculture. Agricultural Water Management 118, 83-95.

Mainuddin, M., Kirby, M., Qureshi, M.E., 2007. Integrated hydrologic-economic modelling for analyzing water acquisition strategies in the Murray River Basin. Agricultural Water Management 93, 123-135.

Maneta, M.P., Torres, M.O., Wallender, W.W., Vosti, S., Howitt, R., Rodrigues, L., Bassoi, L.H., Panday, S., 2009. A spatially distributed hydroeconomic model to assess the effects of drought on land use, farm profits, and agricultural employment. Water Resources Research 45, W11412.

MAPA (Ministerio de Agricultura, Pesca y Alimentación), 2005. Evaluación de la zona regable de Montijo (Badajoz). Spanish Ministry of Agriculture, Fisheries, and Food, Madrid, Spain.

MAPA (Ministerio de Agricultura, Pesca y Alimentación), 2007. Resultados técnicoeconómicos de las explotaciones agrícolas de Extremadura en 2006. Spanish Ministry of Agriculture, Fisheries, and Food, Madrid, Spain.

MARM (Ministerio de Agricultura y del Medio Rural y Marino), 2010. Precios percibidos, pagados y salarios agrarios. Spanish Ministry of the Environment and Rural and Marine Affaires, Madrid, Spain.

McKinney, D., Cai, X., Rosegrant, M.W., Ringler, C., Scott, C.A., 1999. Modeling water resources management at the basin level: review and future directions. In: SWIM Paper, No. 6. International Water Management Institute, Colombo, Sri Lanka.

Medellín-Azuara, J., Mendoza-Espinosa, L.G., Lund, J.R., Harou, J.J., Howitt, R.E., 2009. Virtues of simple hydro-economic optimization: Baja California, Mexico. Journal of Environmental Management 90, 3470-3478.

Mitchell, T.D., Jones, P.D., 2005. An improved method of constructing a database of monthly climate observations and associated high-resolution grids. International Journal of Climatology 25, 693-712.

MMA (Ministerio de Medio Ambiente), 2001. Real Decreto Legislativo 1/2001, de 20 de julio, por el que se aprueba el texto refundido de la Ley de Aguas. Spanish Ministry of Environment, Madrid, Spain.

Molden, D., Oweis, T., Steduto, P., Bindraban, P., Hanjra, M.A., Kijne, I., 2010. Improving agricultural water productivity: between optimism and caution. Agricultural Water Management 97, 528-535.

Nash, J.E., Sutcliffe, J.V., 1970. River flow forecasting through conceptual models part I - a discussion of principles. Journal of Hydrology 10, 282-290.

Neitsch, S.L., Arnold, J.G., Kiniry, J.R., Williams, J.R., 2011. SWAT- Soil And Water Assessment Tool. Theoretical documentation. Version 2009. Texas Water Resources Institute, Texas, USA. Technical Report 406.

Nowicki, P., Goba, V., Knierim, A., Van Meijl, H., Banse, M., Delbaere, B., Helming, J., Hunke, P., Jansson, K., Jansson, T., Jones-Walters, L., Mikos, V., Sattler, C., Schlaefke, N., Terluin, I., Verhoog, D., 2009. Scenar 2020-II - update of Analysis of Prospects in the Scenar 2020 Study. Contract No. 30-CE-0200286/00-21. EC, Directorate-General Agriculture and Rural Development, Brussels.

OECD-FAO, 2009. Agricultural Outlook 2010-2019. On-line database available from: http://www.agri-outlook.org. Last access June 2010.

Oñate, J.J., Atance, I., Bardají, I., Llusia, D., 2007. Modelling the effects of alternative CAP policies for the Spanish high-nature value cereal-steppe farming systems. Agricultural Systems 94, 247-260.

Pulido-Velâzquez, M., Andreu, J., Sahuquillo, A., Pulido-Velázquez, D., 2008. Hydroeconomic river basin modelling: the application of a holistic surface-groundwater model to assess opportunity costs of water use in Spain. Ecological Economics 66, 51-65.

Purkey, D., Joyce, B., Vicuna, S., Hanemann, M.W., Dale, L.L., Yates, D., Dracup, J.A. 2008. Robust analysis of future climate change impacts on water for agriculture and other sectors: a case study in the Sacramento Valley. Climate Change 87 , $109-122$.

Qureshi, M., Qureshi, S., Bajracharya, K., Kirby, M., 2008. Integrated biophysical and economic modelling framework to assess impacts of alternative groundwater management options. Water Resources Management 22, 321-341.

Reidsma, P., Ewert, F., 2008. Regional farm diversity can reduce vulnerability of food production to climate change. Ecology and Society 13 (1), 38

Riegels, N., Jensen, R., Bensasson, L., Banou, S., Møller, F., Bauer-Gottwein, P., 2011. Estimating resource costs of compliance with EU WFD ecological status requirements at the river basin scale. Journal of Hydrology 396, 197-214.

Rosenthal, R.E., 2012. GAMS - a User's Guide. GAMS Development Corporation, Washington, DC, USA. Available from: www.gams.com.

Rounsevell, M.D., Annetts, J.E., Audsley, E., Mayr, T., Reginster, I., 2003. Modelling the spatial distribution of agricultural land use at the regional scale. Agriculture. Ecosystems \& Environment 95, 465-479.

Schulla, J., 2012. Model Description WaSiM (Water Balance Simulation Model). ETH, Zürich.

Sieber, J., Purkey, D., 2011. User Guide for WEAP21 (Water Evaluation And Planning System). Stockholm Environment Institute. Available online from: www. weap21.org.

Smit, B., Skinner, M.W., 2002. Adaptation options in agriculture to climate change: a typology. Mitigation and Adaptation Strategies for Global Change 7, 85-114.

Varela-Ortega, C., 2007. Policy-driven determinants of irrigation development and environmental sustainability: a case study in Spain. In: Molle, F. Berkoff, J. (Eds.), Irrigation Water Pricing Policy in Context: Exploring the Gap between Theory and Practice, Comprehensive Assessment of Water 
Management In Agriculture. IWMI/CABI, Wallingford UK, Cambridge MA USA, pp. 328-346.

Varela-Ortega, C., 2011. The water policies in Spain: balancing water for food and water for nature. In: Ingram, H., Garrido, A. (Eds.), Water for Food: Quantity and Quality in a Changing World, Rosenberg International Forum on Water Policy. Routledge Publisher, Taylor and Francis Group, Abingdon, UK, pp. 262-308.

Varela-Ortega, C., Blanco-Gutiérrez, I., Swartz, C., Downing, T.E., 2011. Balancing groundwater conservation and rural livelihoods under water and climate uncertainties: an integrated hydro-economic modeling framework. Global Environmental Change 21 (2), 604-619.

Von Neuman, J., Morgenstern, O., 1944. Theory of Games and Economic Behavior. Princeton University Press, Princeton, NJ.

Ward, F.A., Michelsen, A., 2002. The economic value of water in agriculture: concepts and policy applications. Water Policy 4, 423-446.

Ward, F.A., Pulido-Velázquez, M., 2008. Water conservation in irrigation can increase water use. Proceedings of the National Academy of Sciences of the United States of America 105, 18215-21822.

Ward, F.A., Pulido-Velázquez, M., 2009. Incentive pricing and cost recovery at the basin scale. Journal of Environmental Management 90, 293-313.
WL Delft Hydraulics, 2004. Technical Reference Manual of RIBASIM, Version 6.32 WL Deflt Hydraulics, Delft, Holland.

World Bank, 2006. Reengaging in Agricultural Water Management Challenges and Options. Washington, D.C

Yang, W., Rousseau, A.N., Boxall, P., 2007. An integrated economic-hydrologic modeling framework for the watershed evaluation of beneficial management practices. Journal of Soil and Water Conservation 62 (6), 423-432.

Yates, D., Sieber, J., Purkey, D., Huber-Lee, A., 2005. WEAP21-A Demand-, priorityand preference-driven water planning model - part 1: model characteristics. Water International 30, 487-500.

Yates, D., Purkey, D., Sieber, J., Huber-Lee, A., Galbraith, H., West, J., Herrod-Julius, S. Young, C. Joyce, B., Rayej, M. 2009. Climate driven water resources model of the Sacramento Basin, California. Journal of Water Resources Planning and Management 135 (5), 303-313.

Young, C.A., Escobar-Arias, M.I., Fernandes, M., Joyce, B., Kiparsky, M., Mount, J.F. Mehta, V.K., Purkey, D., Viers, J.H., Yates, D., 2009. Modeling the hydrology of climate change in California? Sierra Nevada for subwatershed scale adaptation. JAWRA Journal of the American Water Resources Association 45, 1409 1423 